Instytut Archeologii

Uniwersytetu Mikołaja Kopernika

w Toruniu

Mirostawa Zabilska

\title{
DEPOZYTY ZE SZCZĄTKAMI MIĘCZAKÓW NA STANOWISKACH KULTURY ŁUŻYCKIEJ Z POLSKI. CHARAKTERYSTYKA I PRÓBA OKREŚLENIA ICH GENEZY
}

Zarys treści. W niniejszym artykule zgromadzono, dostępne w literaturze przedmiotu, dane na temat depozytów ze szczątkami mięczaków, odkrytych na stanowiskach kultury łużyckiej z ziem polskich. Ich szczegółowa charakterystyka malakologiczna i kontekstowa (archeologiczna) stały się podstawą do próby określenia ich genezy na stanowiskach archeologicznych. W opracowaniu podkreślono rolę mięczaków, nie tylko w gospodarce i symbolice społeczności pradziejowych, ale również w analizach paleoklimatu i zmian zachodzących w środowisku.

\section{Wstęp}

Od najdawniejszych czasów człowiek wykorzystuje zasoby środowiska naturalnego $\mathrm{w}$ celu zaspokojenia zapotrzebowania na pożywienie oraz surowce, dokonuje się to między innymi przez tzw. zbieractwo. Z różnym nasileniem i w odmiennych postaciach, towarzyszy ono ludzkości od prahistorii do czasów nowożytnych. Również ludność kultury łużyckiej, zasiedlająca ziemie polskie od III okresu epoki brązu do początków wczesnego okresu lateńskiego ${ }^{1}$ (tj. XIII-V wiek p.n.e.), obok łowiectwa i rybołówstwa wykorzystywała zbieractwo jako zajęcie dodatkowe, uzupełniające i urozmaicające bazę żywieniową oraz surowcową. Pozyskiwano nie tylko różnorodne rośliny, ale też zwierzęta, zarówno drobne kręgowce, jak i bezkręgowce².

\footnotetext{
${ }^{1} \mathrm{~W}$ dalszej części artykułu w odniesieniu do chronologii stanowisk zastosowano następujące skróty: EB - epoka brązu, Ha - okres halsztacki, La - okres lateński.

${ }^{2}$ Podział podkrólestwa wielokomórkowców (Metazoa) na dwie grupy - bezkręgowce (Invertebrata) i kręgowce (Vertebrata) wprowadził w XIX w. francuski biolog J. B. Lamark (17441829). Mimo, że jest on sztuczny, ponieważ uwzględnia tylko jedno kryterium, obecność lub brak kręgosłupa, wciąż znajduje zastosowanie (Jura 1996, s. 17).
} 
Współcześnie bezkręgowce należą do cenionych dóbr konsumpcyjnych, szczególnie w krajach strefy śródziemnomorskiej, regionu wschodnio-azjatyckiego, wybrzeży Pacyfiku oraz północnej części Europy. „Człowiek zjada paręset gatunków małży, nie mniej ślimaków, wiele gatunków głowonogów, a nawet wielkie chitony" (Falniowski 2001, s. 301). Na tej podstawie można założyć, że dawne środowisko, w którym żył człowiek, było również zasobne w wymienione zwierzęta i podobnie jak współcześnie stanowiły one surowiec dostarczający wartościowych składników odżywczych. Mogą na to wskazywać wielkie składy pustych muszli ostryg (Ostrea), omułka (Mytilus) i sercówki (Cardium), jakie odkryto na stanowiskach litoralnych na północnym wybrzeżu Hiszpanii oraz na wybrzeżach Jutlandii i wysp duńskich. Takie stanowiska określane są terminem duńskim ,kjökkebmedding” lub hiszpańskim „conchero”. Liczne „,́́mietniska muszlowe”3 odkryto też na północnych wybrzeżach Morza Śródziemnego - w południowych Włoszech, na Sycylii i wyspach greckich (Kozłowski 2004, s. 676). Muszle wielkich nilowych Aspatharia i Mutela archeolodzy znajdują w Palestynie, Grecji, Tunezji i Egipcie, na stanowiskach datowanych od 10000 roku p.n.e. po V wiek n.e. (Reese, Mienis, Woodward 1986; Falniowski 2001, s. 301).

Mimo szerokiego spektrum występowania w przyrodzie oraz wielości gatunków, szczątki bezkręgowców są znajdowane na stanowiskach archeologicznych znacznie rzadziej niż pozostałości kręgowców, a ich obecność często jest przypadkowa. Taką sytuację dobrze odzwierciedlają dane archeozoologiczne opublikowane w 21 zeszytach „Archeozoologii” - tylko wyjatkowo pojawiają się oznaczenia pozostałości tej grupy zwierząt, a właściwie jedynie mięczaków. Można przypuszczać, że szersze wykorzystanie bezkręgowców przez populacje pradziejowe bywa zniekształcone lub całkowicie nieuchwytne w materiałach wykopaliskowych z uwagi na specyfikę ich budowy - brak kostnego wewnętrznego szkieletu osiowego w postaci kręgosłupa oraz małe rozmiary wielu gatunków. W osadach naturalnych i warstwach kulturowych dobrze zachowują się szczątki tylko nielicznej grupy bezkręgowców; są to pozostałości organizmów wytwarzających pewne formy szkieletu zewnętrznego. Należą do nich między innymi przedstawiciele dwóch typów: stawonogów (Arthropoda), głównie skorupiaków (Crustacea) oraz mięczaków

\footnotetext{
${ }^{3}$ Szeroko stosowany termin ,śmietniska muszlowe” oznacza depozyty o zróżnicowanym charakterze i wielkości, które łączy obecność szczątków mięczaków. Większość z nich ma charakter jam śmietniskowych, zawierających wyłącznie materiał malakologiczny lub - obok niego - również kości ryb, ptaków, ssaków, rzadziej pancerze skorupiaków i szczątki szkarłupni oraz fragmenty naczyń ceramicznych i innych artefaktów (Kurzawska 2008, s. 59).
} 
(Mollusca) - małży (Bivalvia, Lamellibranchiata) i ślimaków (brzuchonogi, Gastropoda) (Jura 1971; Kawecki 1988). Nieliczne szczątki przedstawicieli innych grup bezkręgowców znajdowane są w osadach czwartorzędowych Polski sporadycznie (Skompski 1991, s. 7). Gromada skorupiaków bardzo rzadko reprezentowana jest przez pozostałości pancerzy raków ${ }^{4}$, jak dotąd nie stwierdzono ich obecności w materiałach archeozoologicznych z zespołów osadniczych ludności kultury łużyckiej. W przypadku mięczaków najczęstszymi pozostałościami znajdowanymi na stanowiskach archeologicznych z ziem polskich są muszle małży z rodziny skójkowatych (Unionidae) (m.in. Dzięczkowski 1998, s. 100), rzadziej skorupy ślimaków wodnych i lądowych (np. Dzięczkowski, Ostoja-Zagórski 1976, s. 319-353; Dzięczkowski 1984, s. 185-192; 2004, s. 139-146).

Niniejsze opracowanie ma na celu scharakteryzowanie niektórych depozytów muszlowych ze stanowisk kultury łużyckiej na ziemiach polskich oraz próbę określenia ich pochodzenia. Istotą artykułu jest również wskazanie znaczenia mięczaków oraz depozytów ich szczątków na stanowiskach archeologicznych, jako wskaźników zmian środowiska przyrodniczego i „bioinformatorów" o charakterze działalności człowieka.

\section{Specyfika materiałów malakologicznych}

Małże (Bivalvia) i ślimaki (Gastropoda) wraz z trzema innymi gromadami - jednotarczowcami (Monoplaccophora), walconogami (Scaphopoda) i głowonogami (Cephalopoda) - tworzą podtyp skorupowców (Conchifera). Najbardziej charakterystyczną cechą tych zwierząt jest obecność jednolitej lub dwuklapowej muszli (skorupki) wapiennej, która jest wytwarzana przez płaszcz (część skóry) pokrywający grzbietową część ciała (Piechocki 1979, s. 7).

Muszla chroni ciało mięczaka przed utratą wody, urazami mechanicznymi, drapieżnikami, czynnikami chemicznymi itp. Na przykład w przypadku obniżenia się poziomu wody zbiorników, gdy małże i ślimaki wodne znajdują się poza naturalnym środowiskiem bytowania, skorupka chroni Conchifera przed wyschnięciem. Pełni też ona ważną rolę szkieletową, jest przeważnie - ze względu na bardzo uwodnione ciało mięczaków - jedynym sztywnym elementem i stanowi miejsce przyczepu głównych mięśni ciała (Wiktor

\footnotetext{
${ }^{4}$ Przykładem są pojedyncze szczątki raka zidentyfikowane we wczesnośredniowiecznych materiałach archeozoologicznych z grodziska w miejscowości Góra, koło Poznania (stanowisko 1) i z Kałdusa, koło Chełmna (stanowisko 3) (ustna informacja prof. dr. hab. D. Makowieckiego z Instytutu Archeologii UMK).
} 
2004, s. 9). Muszla podlega silnemu oddziaływaniu czynników zewnętrznych środowiska i ulega rozmaitym modyfikacjom w zależności od genotypu mięczaka i czynników selekcyjnych otoczenia. Dlatego z jednej strony jest ona nośnikiem cech gatunkowych, z drugiej zaś wykazywać może znaczną zmienność wywołaną presją środowiska, w którym bytowało dane zwierzę (Wiktor 2004, s. 9). Warunki ekologiczne mogą wywierać duży wpływ na kształt i wielkość muszli, co sprawia, że populacje tego samego gatunku żyjące w odmiennych biotopach znacznie się niekiedy różnią. Na przykład muszle osobników zamieszkujących zbiorniki bogate w pokarm, zasobne w wapń i dobrze natlenione $z$ reguły są silniejsze i większe niż muszle ślimaków zasiedlających zbiorniki dystroficzne o kwaśnej wodzie (Piechocki 1979, s. 30).

Podstawowymi warunkami niezbędnymi do zachowania się muszli w warstwach osadów geologicznych jest odpowiedni w nich poziom koncentracji węglanu wapnia $\left(\mathrm{CaCO}_{3}\right)$ oraz odczyn gleby mierzony zawartością $\mathrm{pH}$. W przypadku tego ostatniego najbardziej korzystna jest wartość $>5,5$ (Dzięczkowski 1998, s. 98). Sedymenty o takich właściwościach sprawiają, że muszle mięczaków stanowią jedną z najliczniejszych grup makroszczątków organicznych rejestrowanych w osadach czwartorzędowych na równi z kostnymi pozostałościami zwierząt kręgowych i ze szczątkami roślinnymi. Ponadto mięczaki odznaczają się stosunkowo dużą liczbą taksonów, w skali światowej jest to ponad 34 tysiące gatunków współczesnych (Boss 1971, s. 81-135), krajowej zaś około 260 gatunków, w tym 173 gatunki ślimaków lądowych (Riedel 1988), 46 gatunków ślimaków słodkowodnych (Piechocki 1979) oraz 36 gatunków małży (Urbański 1957, s. 231-266; Piechocki 1989, s. 249-320) - pięć występujących w wodach Morza Bałtyckiego i 31 słodkowodnych.

Puste muszle ślimaków i małży, z reguły pochodzące od osobników ginących na miejscu ich znalezienia lub w jego najbliższym sąsiedztwie, tworzą subfosylne zgrupowanie, czyli konchocenozę ${ }^{5}$. Mimo pewnych rozbieżności występujących między strukturą malakocenozy ${ }^{6}$ i konchocenozy, ta druga jest wskaźnikiem kontrolnym w odniesieniu do zespołu organizmów żywych (ryc. 1). Równolegle do ilościowych badań malakofauny współczesnej, w Polsce (więcej informacji - Riedel, Pokryszko 1999) i na świecie rozwijają się prace nad problemami tzw. rekonstrukcji paleośrodowiska, które opierają się

\footnotetext{
${ }^{5}$ Od łacińskiego słowa concha, czyli muszla.

${ }^{6}$ Wielogatunkowy zespół mięczaków występujących w danej biocenozie, cechujący się wzajemnymi powiązaniami i zależnościami, uzależnionych pokarmowo od zbiorowiska roślinnego (Encyklopedia 2007, s. 766).
} 


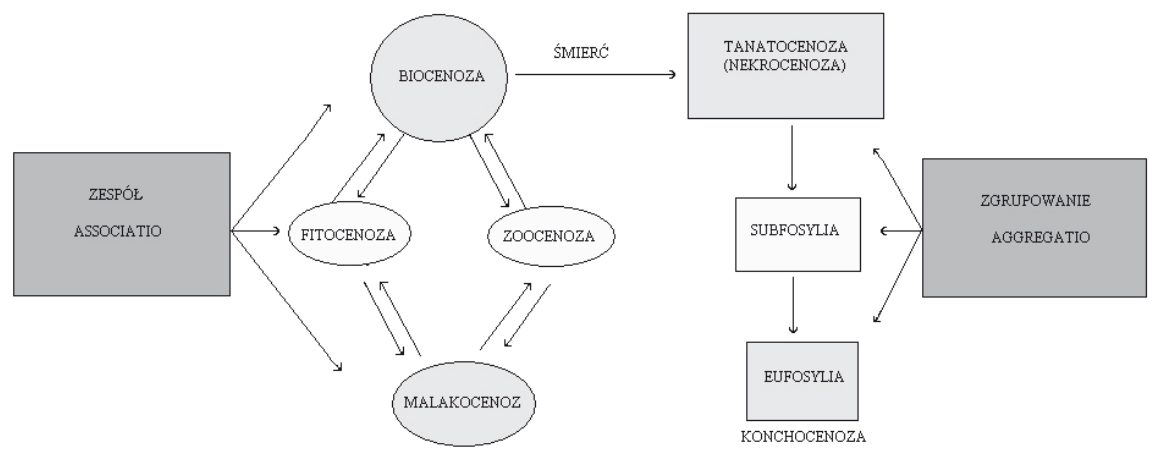

Ryc. 1. Schemat wzajemnych zależności malakocenozy i konchocenozy (wg Dzięczkowski 1988)

Fig. 1. Inter-relationship of malacocenosis and conchocenosis diagram (according to Dzięczkowski 1988)

na analizie subfosylnych zgrupowań (m.in. Kowalkowski, Berger 1966, s. 27; Alexandrowicz 1983, s. 117-158; 1984, s. 40-47; 1996, s. 73-94; Barga-Więcławska 2009a). Celem malakologów przy pobieraniu próbek do oceny zespołów ślimaków w określonych zbiorowiskach roślinnych jest między innymi uwzględnienie konchocenozy, gdyż z biegiem czasu pozwoli to na wypracowanie „porównawczych wzorców standardowych” umożliwiających poprawne interpretowanie subfosylnych zgrupowań (Dzięczkowski 1988, s. 11, 12), pochodzących między innymi ze stanowisk archeologicznych.

Jako zwierzęta charakteryzujące się wysoką specjalizacją ekologiczną, mięczaki są dobrymi bioindykatorami środowiskowymi, dlatego w badaniach geologicznych i archeologicznych stanowią niezmiernie ważną, wskaźnikową grupą organizmów. Niektóre gatunki żyją w wąskich niszach ekologicznych; na przykład, każdorazowa zmiana wilgotności, światła, temperatury, składu chemicznego czy zanieczyszczenie środowiska może powodować ich wymarcie na danym obszarze, a z czasem zastąpienie innymi gatunkami, którym odpowiadają nowe warunki środowiskowe. Identyfikacja gatunkowa poparta wiedzą aktualistyczną na temat ich współczesnych siedlisk, biologii i ekologii (por. uwagi w kolejnym rozdziale; szczegółowe dane o ekologii ślimaków - m.in. Wiktor 2004; Barga-Więcławska 2009a; 2009b, s. 26-29) pozwala na interpretację środowiskową znalezisk mięczaków w poszczególnych kontekstach archeologicznych. Dzięki obecności szczątków malakologicznych w warstwach i obiektach kulturowych, można w pewnym zakresie wnioskować o charakterze paleośrodowiska i niektórych procesów w nim zachodzących, najczęściej w wyniku antropopresji, oraz o pochodzeniu warstw tworzących dany obiekt archeologiczny, a niekiedy również o wieku osadów 
(duże nagromadzenia muszli mogą być datowane metodą $\mathrm{C}^{14}$ ) i wreszcie o możliwościach użytkowania mięczaków w celach konsumpcyjnych przez populacje pradziejowe (Dzięczkowski, Ostoja-Zagórski 1976, s. 321).

Muszle mięczaków zachowane w osadach czwartorzędowych i starszych pomagają w „odczytaniu zapisu kopalnego” ewolucji Ziemi (Dzik 1992), służą jako wskaźniki przy odtwarzaniu historii gleb, mają również duże znaczenie w rekonstrukcji warunków ekologicznych panujących w plejstoceńskich i holoceńskich zbiornikach słodkowodnych.

Znaczenie części mięczaków w przyrodzie, a pośrednio również w gospodarce człowieka jest bardzo duże. Pewne gatunki są żywicielami stadiów larwalnych przywr, których formy dorosłe pasożytują w organizmie człowieka, lub zwierząt domowych. Mięczaki stanowią podstawową biomasę niektórych mórz, wiele z niech jest pokarmem zwierząt (np. ryb odżywiających się bentosem, ssaków i ptaków bytujących w pobliżu wody) i - jak wyżej wspomniano - także człowieka. Duże znaczenie ślimaków polega również na tym, że jako konsumenci tkanek roślinnych, detrytusu i martwych zwierząt stanowią ważne ogniwo w obiegu substancji organicznych w zbiornikach wodnych (Piechocki 1979, s. 57).

Bezpośrednie znacznie gospodarcze mięczaków występujących w Polsce jest niewielkie. Pojawiające się niekiedy masowo ślimaki wodne bywają odławiane wraz z rzęsą wodną i podawane kaczkom hodowanym w fermach jako wartościowy pokarm uzupełniający (Piechocki 1979, s. 57). Specyficzna biologia i fizjologia mięczaków sprawia, że są one również doskonałymi obiektami różnych laboratoryjnych eksperymentów biologicznych czy medycznych (Dzięczkowski 1998, s. 99). Na przykład powszechnie występujące i łatwe do hodowania ślimaki Lymnaea stagnalis i gatunki z rodziny Viviparus sa częstym obiektem badań fizjologicznych, histologicznych, cytologicznych i embriologicznych (Piechocki 1979, s. 57).

Muszle ślimaków wodnych i małży wchodzą w skład kredy jeziornej, która ma zastosowanie jako wapno nawozowe w rolnictwie, dodatek do pasz i nośnik środków owadobójczych (Piechocki 1979, s. 57). Mięczaki były dawniej i są obecnie źródłem barwników naturalnych ${ }^{7}$, wytwarza się z niech bi-

\footnotetext{
${ }^{7}$ Wszystkie ślimaki mają gruczoł nadskrzelowy, którego śluzowata wydzielina u wielu gatunków zawiera także toksyny paraliżujące atakowaną ofiarę. W przypadku trzech gatunków śródziemnomorskich ślimaków, należących do drapieżnych rozkolcowatych (Muricidae): Trunculariopisis trunculus, Bolinus brandaris i Thais haemastoma wydzielina tego gruczołu, bezbarwna w momencie ekstrakcji, pod wpływem światła staje się zielonkawa, później brunatna, aby na koniec uzyskać trwałą purpurową barwę. W ten sposób powstaje niezwykle kosztowny i ceniony niegdyś barwnik używany do drogich szat - słynna purpura tyryjska, zwana też królewską (Falniowski 2001, s. 305, 306).
} 
żuterię (perły), stanowią też surowiec do produkcji ozdób (muszle, „masa perłowa") (Kawecki 1988, s. 189). W materiałach archeologicznych również znajdowane są egzemplarze wskazujące na wykorzystanie muszli do wyrobu ozdób, przedmiotów codziennego użytku, narzędzi lub posługiwania się nimi jako domieszką w produkcji naczyń ceramicznych (Kurzawska 2008, s. 59-63). Szerokie zastosowanie muszli krajowych małży słodkowodnych potwierdzają przekazy etnograficzne. Wiadomo, że do niedawna nad Wkrą rozwijała się chałupnicza produkcja guzików „z masy perłowej”; bazę surowcową stanowiły muszle licznie występujących w polskich rzekach i jeziorach różnych gatunków małży. Z małży należących do rodziny skójkowatych pozyskiwano też perły. Na ziemiach polskich perłoródka znajdowała odpowiednie warunki wyłącznie w czystych wodach Sudetów, była tam jednak tak powszechna, że jeszcze podczas I wojny światowej karmiono nią świnie. Obecnie mięczak ten nie występuje w naszym kraju, jako jedyny został całkowicie wytępiony (Falniowski 2001, s. 313).

Interesujący przykład użytkowania muszli krajowych małży odnotowano w przypadku skójek malarskich (Unio pictorum); są one wykorzystywane przez artystów malarzy do rozdrabniania farb, czemu mięczak ten zawdzięcza swoją nazwę. Jeszcze w drugiej połowie minionego wieku w muszlach tego gatunku rozrabiano złote i srebrne farby, używane w iluminacji manuskryptów (Kawecki 1988, s. 208, 209).

\section{Wymagania ekologiczne mięczaków i ich przydatność $w$ rekonstrukcji środowiska}

Jak wyżej wspomniano, mięczaki stanowią ważną grupę organizmów, tzw. bioindykatorów, wykorzystywaną przy rekonstrukcji warunków klimatycznych panujących w przeszłości oraz paleośrodowiska i jego przemian, między innymi spowodowanych działalnością człowieka. Do takich interpretacji niezbędna jest aktualna wiedza na temat biologii i ekologii zidentyfikowanych gatunków. Dlatego w niniejszym rozdziale pokrótce omówione zostaną wybrane zagadnienia dotyczące wymagań ekologicznych mięczaków.

Pierwotnie mięczaki były bezkręgowcami morskimi i również obecnie największą różnorodność wykazują gatunki bytujące w morzu. Z biegiem czasu niektóre z nich zasiedliły wody słodkie (ślimaki, małże) i lądy (ślimaki). Przeważająca większość żyje wolno, nieliczne grupy są osiadłe. Formy wolno żyjące poruszają się powoli (np. małże i ślimaki lądowe), pełzając po podłożu, albo aktywnie pływają (pelagiczne ślimaki wodne) (Jura 1996, s. 630). Małże 
są mięczakami dennymi, mało ruchliwymi albo osiadłymi, bytują głównie w morzach, jedynie około $1 / 5$ gatunków w różnego rodzaju słodkich wodach śródlądowych. Niektóre żyją zagrzebane w piasku lub mule, inne wnikają w skaliste podłoże lub w przedmioty drewniane zatopione w morzu. Gatunki prowadzące osiadły tryb życia przyczepiają się do podłoża dolną częścią muszli lub za pomocą bisioru - wydzieliny gruczołów nogi (Jura 1971, s. 269). Organizmy te są niezmiernie powolne, na przykład skójka lub szczeżuja potrzebują pół godziny na to, aby przesunąć się w mule o jedną długość swojego ciała (Starmach 1976, s. 376).

Największe bogactwo gatunków występuje w płytkich strefach (do $100 \mathrm{~m}$ ) ciepłych mórz, na piaszczystych dnach, na dużych głębokościach jest ich niewiele. W wodach słodkich występują najliczniej w strefach gorących, ciepłych i umiarkowanych, niewiele jest ich natomiast w strefie polarnej (Jura 1996, s. 674). W jeziorach małże występują najobficiej w strefie łąk podwodnych, które rozciągają się w głębokiej wodzie. Obok dużych skójek i szczeżuj spotyka się tam często formy drobniejsze - kulkówki (Sphaerium) czy groszkówki (Pisidium). Martwe skorupki małży i ślimaków wodnych, unoszone ruchem wody, zsuwają się ku głębinom jeziora i na stromych stokach jego misy tworzą niekiedy usypisko potężnych rozmiarów (Starmach 1976, s. 375, 376).

Najliczniejszą pod względem gatunków gromadę mięczaków stanowią brzuchonogi. Jak już wspomniano są bezkręgowcami przystosowanymi do życia w różnych środowiskach, w wodzie i na lądzie. Najwięcej gatunków występuje w morzach, zwłaszcza płytkich, ciepłych podzwrotnikowych. Brzuchonogi bytujące $\mathrm{w}$ wodach $\mathrm{w}$ przeważającej większości są bentoniczne, związane z jakością podłoża, najliczniej występują na dnach skalistych, w mniejszym stopniu na żwirowych i piaszczystych. W morzach o słabym zasoleniu udział fauny ślimaków jest niewielki. Część brzuchonogów jest pelagiczna (swobodnie pływająca), natomiast nieliczne gatunki są osiadłe (Jura 1996, s. 651, 652). Wśród wód słodkich najbogatszą faunę ślimaków mają jeziora, stawy i małe zbiorniki wodne z obfitą roślinnością. Znacznie mniej występuje ich w wodach płynących (Jura 1996, s. 652).

Większe zróżnicowanie gatunkowe brzuchonogów można zaobserwować na lądach. O ich występowaniu i aktywności w przeważającym stopniu decyduje gospodarka wodna. „Większość z nich to formy wilgociolubne (higrofile) lub zwierzęta związane ze średnią wilgotnością podłoża i atmosfery w swoim bezpośrednim otoczeniu (mezofile). Zdecydowanie sucholubnych (kserofilnych) ślimaków jest niewiele i mają one szczególne przystosowania" (Wiktor 2004, s. 23). Z czynników fizycznych bardzo ważna jest temperatura otocze- 
nia, mięczaki te najczęściej są aktywne w niskich, ale dodatnich temperaturach (przeważnie $5-10^{\circ} \mathrm{C}$ ), jednak wrażliwe zarówno na wysokie, jaki i bardzo niskie temperatury (Wiktor 2004, s. 25). Wszystkie ślimaki potrzebują do prawidłowego funkcjonowania oraz budowy muszli znacznych ilości wapnia. Dlatego szczególnie bogata fauna ślimaków występuje w wodach lub glebach zasobnych w wapń oraz na skałach wapiennych. Deficyt tego składnika jest groźny dla ślimaków, stąd ich niemal zupełny brak w kwaśnych torfowiskach i glebach (Wiktor 2004, s. 25). „Przy tych zależnościach brzuchonogi wykazują na lądach dużą plastyczność, występują zarówno w strefach zimnych, jak i gorących, wilgotnych i suchych. W górach żyją do wysokości $5000 \mathrm{~m}$ n.p.m., a niektóre formy zdołały skolonizować stepy i półpustynie, gdzie wychodzą z kryjówek w poszukiwaniu pokarmu tylko noca, gdy spadnie rosa" (Jura 1996, s. 652). Wiele ślimaków lądowych (również tych występujących w Polsce) chroni się przed suszą i słońcem, a także przed drapieżnikami, między gęstą roślinnością (w trawie, runie leśnym, mchu itp.), pod grudkami ziemi, korą drzew lub w szczelinach skalnych. W miejscach tych wahania wilgotności, przynajmniej dobowe, są niewielkie (Wiktor 2004, s. 24).

Przy próbie określenia ogólnej genezy osadów lądowych, słodkowodnych, morskich (przy założeniu, że fauna znajduje się na pierwotnym złożu), na podstawie określonych zespołów mięczaków, niezbędna jest znajomość wymienionych powyżej wymagań ekologicznych i środowiska życia poszczególnych gatunków.

Na podstawie wiedzy teoretycznej o biologii i ekologii mięczaków V. Ložek (1964) wyróżnił 12 grup ekologicznych (Barga-Więcławska i in. 2002, s. 72; 2009, s. 143):

E-1 - typowe ślimaki leśne,

E-2 - ślimaki występujące głównie w lasach, ale pospolite również w parkach, ogrodach i innych środowiskach o dość dużym zacienieniu,

E-3 - ślimaki leśne i cieniolubne, typowe dla siedlisk wilgotnych (podmokłych),

E-4 - ślimaki stepowe, występujące na stanowiskach suchych i nasłonecznionych,

E-5 - ślimaki siedlisk otwartych (nie zalesionych), związane z siedliskami o różnej wilgotności,

E-6 - ślimaki typowe dla suchych, ciepłych biotopów,

E-7 - ślimaki środowisk o średniej wilgotności,

E-8 - ślimaki występujące w środowisku wilgotnym, 
E-9 - ślimaki siedlisk bardzo wilgotnych, podmokłych, a nawet okresowo podtapianych (tzw. hydrofile),

E-10 - mięczaki okresowo wysychających oczek wodnych, rozlewisk,

E-11 - mięczaki zbiorników wodnych,

E-12 - mięczaki wód płynących.

Dla ziem polskich należało by jeszcze dodać grupę - mięczaki morskie.

Jak wskazuje S. Skompski (1991, s. 83), podział na grupy ekologiczne i zestawienie ich w formie diagramów ułatwia syntetyczną ocenę zespołów mięczaków znalezionych w poszczególnych warstwach, pozwala prześledzić zmiany ilościowe gatunków i osobników w profilu geologicznym. Przy uwzględnieniu warunków geomorfologicznych (paleogeomorfologicznych), rodzaju gleb itp., dane te umożliwiają dokładną i szczegółową interpretację profilu oraz zmian zachodzących w środowisku. Przykłady takich interpretacji, opierających się na wyróżnionych gatunkach należących do konkretnych grup ekologicznych, zaprezentowane zostały między innymi w pracy wymienionego autora (Skompski 1991, s. 84-93) i nie będą tu szerzej omawiane.

Mięczaki, jako ,biologiczny zapis informacji”, stanowią element materiałów faunistycznych pozyskiwanych podczas badań wykopaliskowych i mogą być przesłankę do rekonstrukcji paleośrodowiska oraz interpretacji udziału człowieka w jego przekształceniach.

\section{Stan badań}

Zainteresowanie szczątkami mięczaków znajdowanymi na stanowiskach archeologicznych sięga końca XIX wieku. Jednak za pioniera badań malakologicznych zastosowanych w archeologii uważa się A. S. Kennarda (1870-1948), dzięki któremu zaczęto je w Anglii traktować na równi z palinologią, archeobotaniką oraz osteologią (Dzięczkowski 1998, s. 98). Następstwem takiego programu badawczego są liczne w angielskiej literaturze publikacje analiz malakologicznych depozytów ze stanowisk archeologicznych (m.in. Sparks 1963; Evans 1969), wśród których czołowe miejsce zajmuje podręcznik J. G. Evansa (1972). Poza Anglią również w byłej Czechosłowacji, po zakończeniu II wojny światowej, rozwinęły się na szerszą skalę badania malakologiczne w analizach wszelkiego rodzaju osadów czwartorzędowych; jedną z ważniejszych publikacji jest podręcznik autorstwa V. Ložka (1964). Ponadto w niemieckiej literaturze można znaleźć kilka interesujących prób systematycznego opracowania przez malakologów pozostałości mięczaków ze stanowisk archeologicznych (np. Ant 1971, s. 449-466). 
W Polsce dopiero w okresie międzywojennym zaczęto analizować subfosylne szczątki mięczaków z osadów czwartorzędowych, pochodziły one z badań geologicznych (Urbański 1932, s. 205-209; 1935, s. 8-11). Natomiast pozostałości tych zwierząt, wydobyte podczas badań archeologicznych, zostały omówione tylko w jednej pracy; były to muszle pochodzące z neolitycznych grobów w Złotej koło Sandomierza (Friedberg 1934). Dopiero po II wojnie światowej praktycznie zastosowano malakologię w badaniach archeologicznych - analizowano faunę ślimaków z osadów ze schroniska w Puchaczej Skale w dolinie Prądnika Czajowskiego (Wiktor 1965, s. 28-37). Obecnie w polskiej literatura można już wskazać liczne pozycje dotyczące wykorzystania szczątków mięczaków w badaniach archeologicznych (m.in. Kowalkowski, Berger 1965, s. 443-448; 1966, s. 27; Dzięczkowski 1966; 1969; 1974a; 1974b; 1975; 1984; 1998; 2004; Piechocki 1971; Dzięczkowski, Ostoja-Zagórski 1976, s. 319-353; Kruk i in. 1996).

Niewątpliwie kolejnym etapem w rozwoju badań malakologicznych było wyodrębnienie się tzw. archeomalakologii i podjęcie badań w jej ramach nie tylko przez zoologów lecz także archeologów ${ }^{8}$. W lutym 2000 roku, podczas spotkania The Conchological Society of Great Britain and Ireland (Towarzystwa Konchologicznego Wielkiej Brytanii i Irlandii) w Muzeum Historii Naturalnej w Londynie, utworzono The Archaeomalacology Group. Ponadto w czasie jednodniowej sesji archeomalakologicznej na międzynarodowej konferencji International Council for ArchaeoZoology (ICAZ) w sierpniu 2002 roku w Durham (Anglia) powołano The ICAZ Archaeomalacology Working Group (AMWG). Działalność Grupy oraz spotkania jej członków odbywające się co dwa lata mają na celu wymianę doświadczeń, prezentowanie materiałów malakologicznych pozyskiwanych w trakcie wykopalisk archeologicznych oraz możliwości ich interpretacji czy zastosowania w rekonstrukcji paleośrodowiska itd. Przedostatnie spotkanie AMWG odbyło się w lutym 2008 roku w Santander (Hiszpania) i zaowocowało opublikowaniem tez zaprezentowanych referatów w specjalnym wydaniu Archaeofauny (Molluscs 2008). Przedostatnie spotkanie odbyło się w sierpniu 2010 roku, jako jedna z sesji konferencji ICAZ w Paryżu?.

W starszej literaturze (np. Żurowski 1922, s. 78-145; Węgrzynowicz 1968a, s. 209-248; 1968b, s. 44-59; Podgórski 1971, s. 79-91; Szydłowska 1972)

\footnotetext{
${ }^{8}$ Obecnie w Polsce tymi zagadnieniami zajmuje się między innymi mgr A. Kurzawska z Pracowni Archeobiologicznej w Instytucie Archeologii i Etnologii Polskiej Akademii Nauk w Poznaniu.

${ }^{9}$ Więcej informacji o ICAZ Archaeomalacology Working Group na stronie http://www.alexandriaarchive.org/icaz/index.htm
} 
sygnalizowano jedynie obecność muszli na stanowiskach archeologicznych, rzadko natomiast szczegółowo analizowano materiały malakologiczne pod kątem ich składu gatunkowego, kontekstu występowania, przeprowadzenia próby rekonstrukcji środowiska geograficznego i warunków klimatycznych panujących w pradziejach czy też genezy depozytów muszli w warstwach kulturowych. Stan refleksji nad wartością poznawczą mięczaków dobrze odzwierciedla zdanie, iż „Pozostałości mięczaków często traktowane są jako niewiele znaczący dodatek do analizy szczątków kręgowców" (Kurzawska 2008, s. 59). Mimo, że metodyka badań malakologicznych, zarówno w terenie, jak i w laboratorium, została zaprezentowana w pracy A. Dzięczkowskiego (1998, s. 102-107), to jednak w dalszym ciągu materiał ten bywa lekceważony przez archeologów. Najczęstszym zaniedbaniem i niemalże powszechnym zjawiskiem, jest ręczne kolekcjonowanie jedynie większych, widocznych gołym okiem, lepiej zachowanych okazów. Ze zrozumiałych względów można założyć, że tak zebrany materiał nie stanowi wystarczająco reprezentatywnej próby dla interpretacji elementów paleośrodowiska czy też znaczenia mięczaków w systemie kulturowym danej społeczności.

Według A. Dzięczkowskiego najważniejsze znacznie w badaniach środowiskowych mają mięczaki o małych skorupkach, o rozmiarach 1,3-4,5 $\mathrm{mm}$, czyli tak zwana mezomalacofauna. Należą one bowiem do licznie znajdowanych szczątków malakofauny, na dodatek w różnych nawarstwieniach pochodzenia antropogenicznego ,[...], a przede wszystkim w fosach i rowach wokół grodzisk, w wypełniskach szybów i studni, w jamach zasobowych, nasypach obronnych i kurhanach, w rumowiskach budowli i śmietniskach przydomowych" (Dzięczkowski 1998, s. 101). Z powodu małych rozmiarów większość gatunków, w tym tych będących dobrymi ekologicznymi indykatorami, jest często pomijana podczas wykopalisk. Bywa też tak, że przepłukiwanie sedymentów w warunkach terenowych, zazwyczaj przy zastosowaniu sit o zbyt dużych oczkach, powoduje zagubienie lub zniszczenie znacznej części materiałów. Ponadto archeolodzy zazwyczaj z góry zakładają przypadkowość depozytów muszlowych, które miały powstać w wyniku zjawisk przyrodniczych. Częste jest przekonanie, że nagromadzenie muszli malakofauny środowiska wodnego jest wynikiem wahania poziomu wód w jeziorach i rzekach, wynikającego z powodzi ${ }^{10}$. Taka interpretacja może być uzasadniona w przypadku rozproszonego występowania muszli mięczaków wodnych w warstwach kulturowych lub naturalnych nagromadzeniach mułowych

${ }^{10}$ Jednak również przy niskich stanach rzek, na przykład Odry na wysokości Opola można zaobserwować znaczne ilości małży zagrzebanych w mule i piasku (obserwacje własne autorki). 
(Dzięczkowski, Ostoja-Zagórski 1976, s. 319-353; Narożna-Szamałek 1986, s. 103-132) czy w torfie (Tobolski 2000). Obecność mięczaków na stanowiskach archeologicznych może być również spowodowana przez inne czynniki przyrodnicze, na przykład osuwiska, nasypy czy nawianie. Natomiast szczątki malakologiczne znajdowane w większych skupiskach powstałych na skutek działalności człowieka, w większości stanowią wspomniane już „śmietniska muszlowe” (Kurzawska 2008, s. 59).

\section{Depozyty muszli w kulturze tużyckiej}

Pomimo postępu w rozwoju badań archeomalakologicznych, stan opracowania szczątków mięczaków pozyskanych z warstw i obiektów osadniczych identyfikowanych z kulturą łużycką, wciąż nie jest zadawalający. Dotychczas szczegółowe badania malakologiczne przeprowadzono zaledwie na kilku stanowiskach tej kultury. Opublikowano je dla Jankowa, gm. Pakość (Dzięczkowski, Ostoja-Zagórski 1976, s. 319-353) i Komorowa, gm. Kaźmierz, stanowisko 1 (Dzięczkowski 2004, s. 139-146), w przygotowaniu są kolejne - dla Rudy, gm. Grudziądz, stanowiska 3-6 (Rembisz i in. 2009, s. 109-122), Lutola Mokrego, gm. Trzciel, stanowisko 36, Szestna, gm. Mragowo, stanowisko II (Ptasia Wyspa) (Kurzawska 2008, s. 59-63).

Jak dotąd, muszle mięczaków, niekiedy w znacznych ilościach, wystąpiły w przypadku trzech kategorii punktów osadniczych kultury łużyckiej (ryc. 2; tab. 1):

- na osadach: Kamionka Nadbużna, gm. Nur, stanowisko 1, Kruszwica, gm. Kruszwica, stanowisko K 2/4, Łagiewniki, gm. Kruszwica, stanowisko 5/7, Gacanowo, gm. Kruszwica, stanowisko 11, Ruda, gm. Grudziądz, stanowiska 3-6, Lutol Mokry, gm. Trzciel, stanowisko 36, Szestno, gm. Mrągowo, stanowisko II (Ptasia Wyspa, Będzieszyn (dawniej Juszkowo), gm. Gdańsk, stanowisko 3;

- na grodziskach: Jankowo, gm. Pakość, Komorowo, gm. Kaźmierz, stanowisko 1, Będzin-Grodziec, gm. Jasienica, stanowisko 16 (Góra św. Doroty), Sobiejuchy, gm. Żnin, stanowisko 1, Wrocław-Osobowice;

- na cmentarzyskach: Kamionka Nadbużna, gm. Nur, stanowisko 2, Przeczyce, gm. Mierzęcice, stanowisko 1, Brzegi, gm. Sobków, Nowy Łowicz, gm. Kalisz Pomorski, stanowisko 2.

Pozostałości malakologiczne znajdowane są zarówno w zwartych obiektach archeologicznych, na przykład różnego rodzaju jamach gospodarczych, co może wskazywać na celowe wykorzystywanie mięczaków lub samych muszli, 


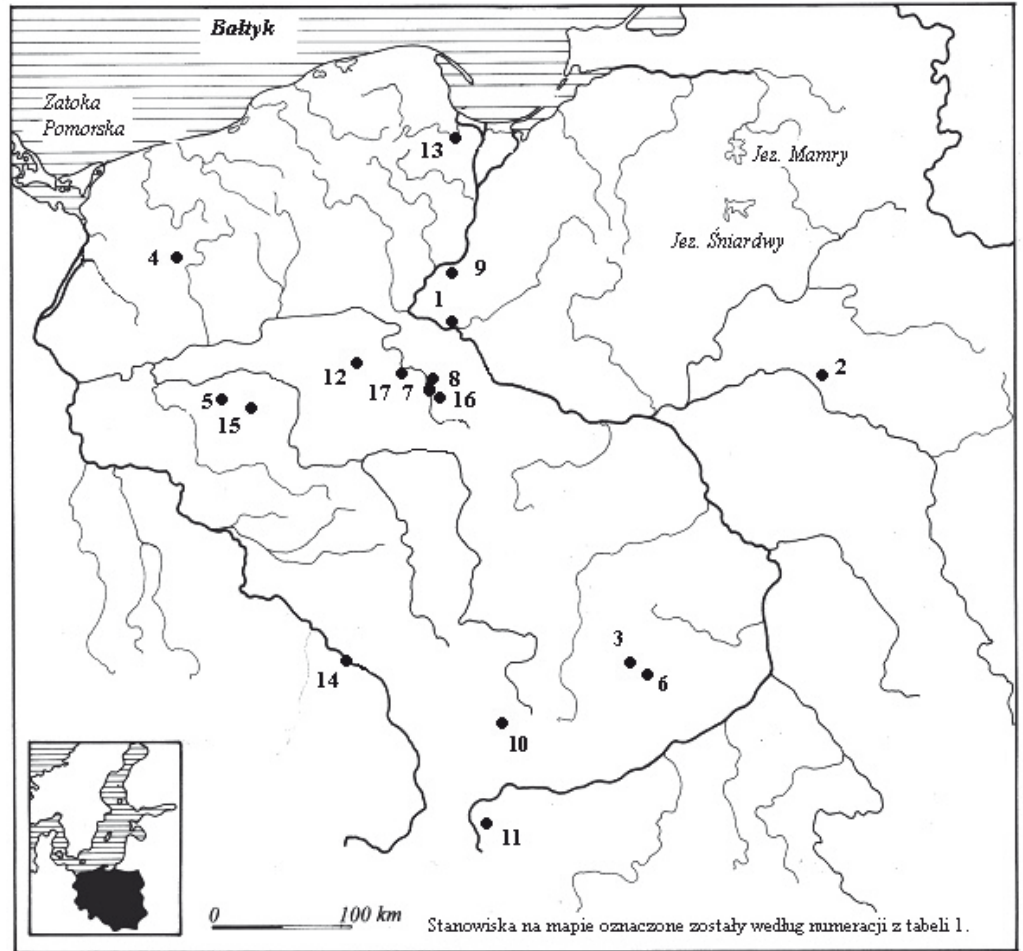

Ryc. 2. Rozmieszczenie stanowiska kultury łużyckiej z depozytami muszlowymi (oprac. M. Zabilska)

Fig. 2. Location of the Lusatian culture sites, where shells concentrations were found (elaborated by M. Zabilska)

jak i w warstwach kulturowych, do których mogły dostać się przypadkowo w wyniku zjawisk przyrodniczych.

W Kamionce Nadbużnej, na terenie osady z młodszej epoki brązu, muszle małży odkryto w dwóch jamach (ryc. 3). W jednej z nich szczątki znaleziono w zniszczonym naczyniu ceramicznym zalegającym w warstwie popiołu i przepalonej ziemi (Węgrzynowicz 1968b, s. 49, ryc. 3). W drugiej (ryc. 4), prawdopodobnie również zawierającej ślady paleniska, muszle odsłonięto wraz z licznymi ułamkami naczyń ceramicznych (tzw. kuchennych) i kości zwierzęcych (Węgrzynowicz 1968b, s. 45, 46, ryc. 1). Charakter obu depozytów może wskazywać na stosowanie przez mieszkańców osady obróbki termicznej (np. w celu przygotowania posiłku) mięczaków.

Podczas badań archeologicznych osady ludności kultury łużyckiej w Kruszwicy odsłonięto 52 obiekty o zróżnicowanym charakterze, wśród nich aż 42 uznano za jamy gospodarcze, najprawdopodobniej w większości zasobowe. 
W wypełniskach kilku z nich stwierdzono obecność szczątków mięczaków ${ }^{11}$ oraz ryb, które wskazują na eksploatację gospodarczą wód Gopła przez lokalną społeczność. Wszystkie z wymienionych obiektów datowano na okres halsztacki (jamy 4, 5 i 40 - okres $\mathrm{HaC}$, jama 13 - okres HaD). Na pozostałości malakologiczne natrafiono również w dwóch (z trzech zidentyfikowanych) paleniskach ${ }^{12}$ zbudowanych z kamieni polnych o średnicy 5-30 cm (Narożna-Szamałek 1986, ryc. 7). Jedno z nich (obiekt nr 1) datowano na okres $\mathrm{HaC}$, w przypadku drugiego (obiekt $\mathrm{nr}$ 6) chronologia nie została dokładnie określona. W wypełniskach jam paleniskowych, poza szczątkami malakologicznymi odnotowano spaleniznę z soczewkami gliny, ułamki naczyń ceramicznych (obiekt nr 1) oraz kości ryb (obiekt nr 6) (Narożna-Szamałek 1986, s. 114). Wśród odsłoniętych na omawianym stanowisku obiektów tylko siedem można było zaliczyć do mieszkalnych; były to pozostałości czterech ziemianek o nieregularnych kształtach, których powierzchnia na poziomie glin zwałowych przekraczała $3 \mathrm{~m}^{2}$ (Narożna-Szamałek 1986, s. 111, ryc. 3, 4, 6). $\mathrm{W}$ wypełnisku jednej z nich (obiekt $\mathrm{nr}$ 10) datowanej na okres $\mathrm{HaC} / \mathrm{HaD}$, stwierdzono 1300 szczątków malakologicznych. Pozostałości te należały do siedmiu gatunków mięczaków wodnych charakterystycznych dla przybrzeżnej strefy jezior, głównie jednak skójki (Unio sp.) i szczeżui (Anodonta sp.) (Narożna-Szamałek 1986, tab. 1).

Charakter pozostałości malakologicznych w wymienionych wyżej jamach zasobowych (śmietnikowych) i paleniskowych skłania do interpretowania ich jako śladów gospodarczego wykorzystania mięczaków, natomiast nagromadzenie muszli w obiekcie nr 10 jest trudniejsze do wyjaśnienia. Po pierwsze, w jamie tej warstwa muszli przykrywała wieloosobowy pochówek (Narożna-Szamałek 1986, s. 111, ryc. 6; Dzieduszycki 1993, s. 92, ryc. 5). W dolnej części wypełniska wyróżniono szczątki dwóch osobników dorosłych i dwojga dzieci. W trzech poziomach wypełniska ziemianki znajdowały się fragmenty szkieletu jednego osobnika dorosłego, obok nich kości dziecka zmarłego w wieku 4-6 lat oraz noworodka. Ze szczątków drugiego osobnika dorosłego zachowała się jedynie żuchwa. Wiek osobników dorosłych określono na 25-40 lat. $\mathrm{Na}$ fragmentach kostnych nie stwierdzono zmian patologicznych po przebytych schorzeniach, wszystkie zauważalne uszkodzenia powstały najprawdopodobniej pośmiertnie. Prawie kompletnie zachowany szkielet dorosłego osobnika był tak ułożony, że tułów spoczywał w górnej części ziemianki, natomiast

\footnotetext{
${ }^{11}$ Muszle mięczaków znaleziono w jamach gospodarczych nr 4 (38 szt.), 5 (5 szt.), 13 (15 szt.) i 40 (1 szt.) (Narożna-Szamałek 1986, s. 114, tab. 1).

${ }^{12} \mathrm{~W}$ obiekcie $\mathrm{nr} 1$ były to dwie muszle, w obiekcie nr 6 jedna.
} 
[268]

\begin{tabular}{|c|c|c|c|c|c|c|c|c|c|c|c|}
\hline & & 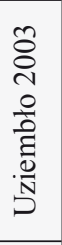 & 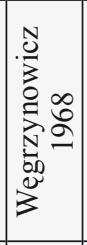 & 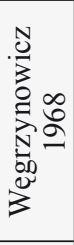 & 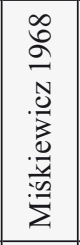 & $\begin{array}{l}\frac{\sigma}{\sigma} \\
\frac{\pi}{\tilde{J}} \\
\frac{\pi}{\pi} \\
\frac{\pi}{I}\end{array}$ & 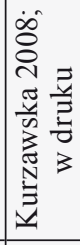 & 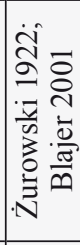 & & 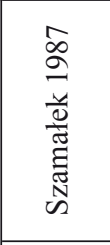 & 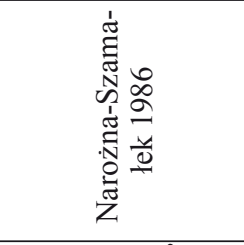 \\
\hline 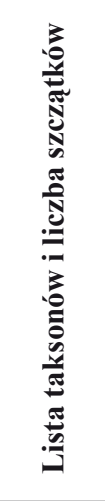 & & 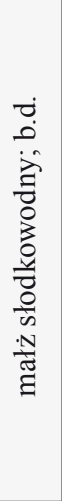 & 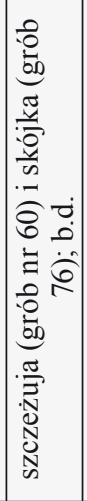 & 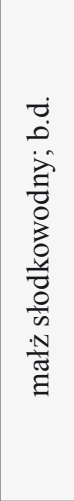 & 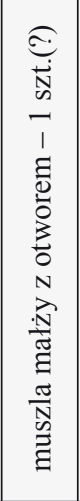 & 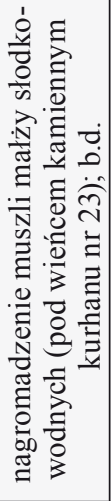 & 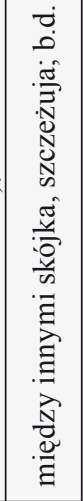 & 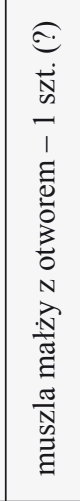 & $\frac{\pi}{0}$ & 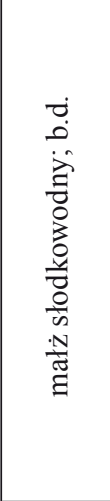 & 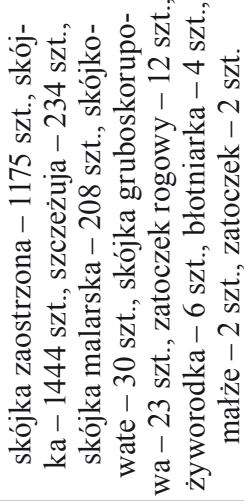 \\
\hline 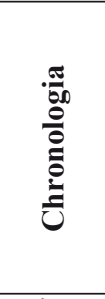 & 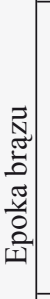 & 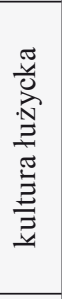 & 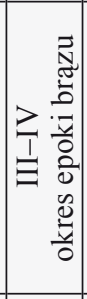 & 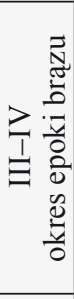 & 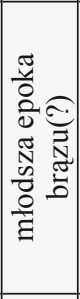 & 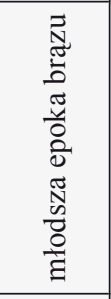 & 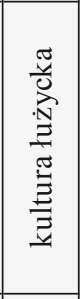 & 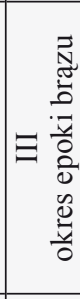 & 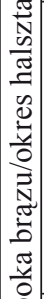 & 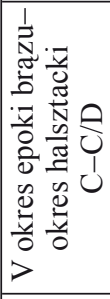 & 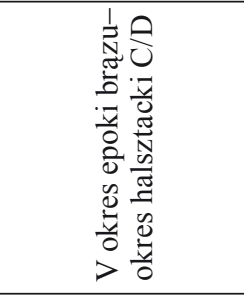 \\
\hline 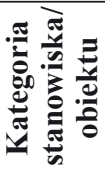 & & 点 & 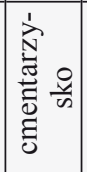 & 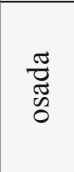 & 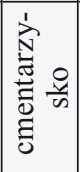 & 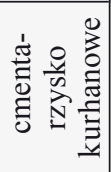 & $\begin{array}{l}\frac{\pi}{\tilde{Z}} \\
\tilde{0} \\
\tilde{0}\end{array}$ & 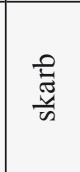 & 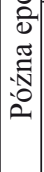 & $\begin{array}{l}\tilde{J} \\
\mathbb{Z} \\
0 \\
0\end{array}$ & 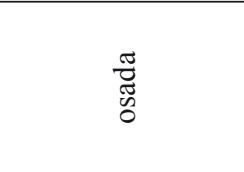 \\
\hline 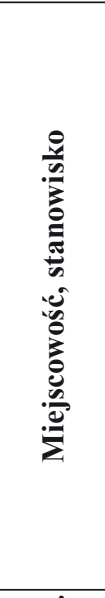 & & 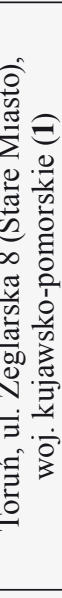 & 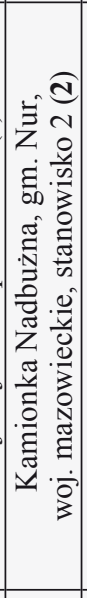 & 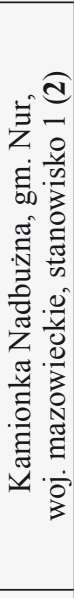 & 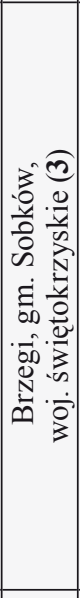 & 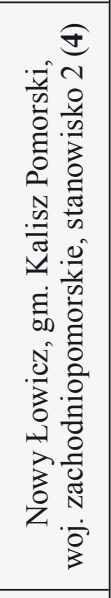 & 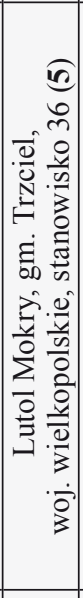 & 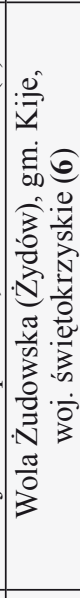 & & 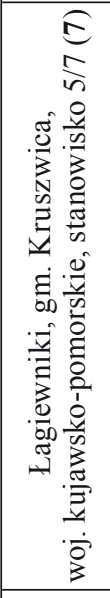 & 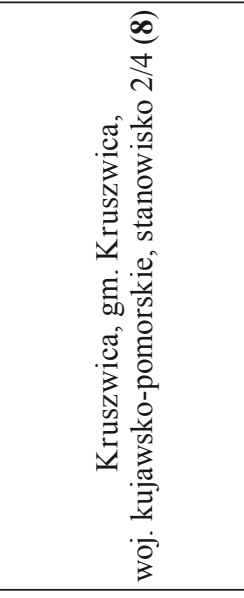 \\
\hline$\dot{1}$ & & - & $\sim$ & $m$ & $\nabla$ & in & 0 & $r$ & & $\infty$ & $a$ \\
\hline
\end{tabular}


[269]

\begin{tabular}{|c|c|c|c|c|c|c|c|c|c|c|}
\hline 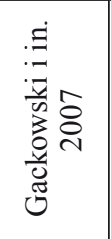 & 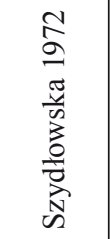 & 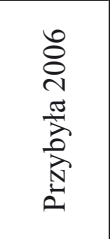 & 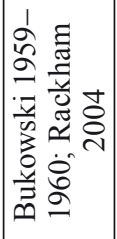 & 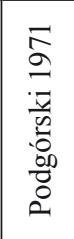 & 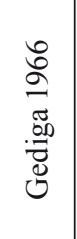 & & 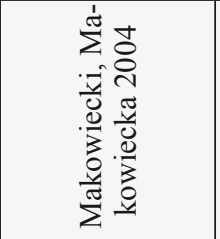 & 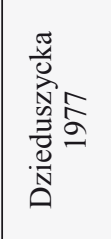 & & 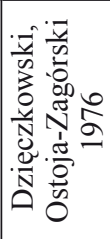 \\
\hline 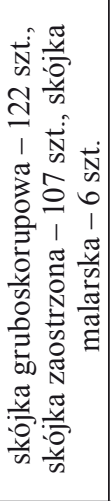 & 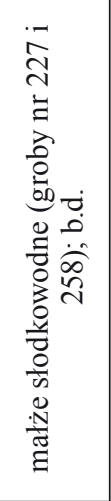 & 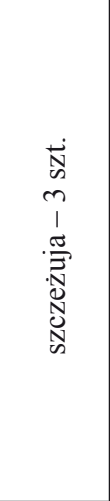 & 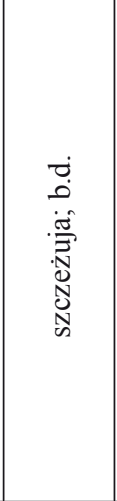 & 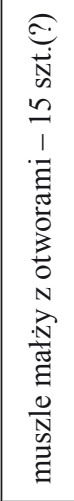 & 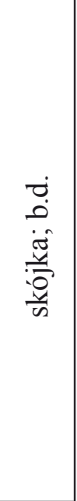 & & 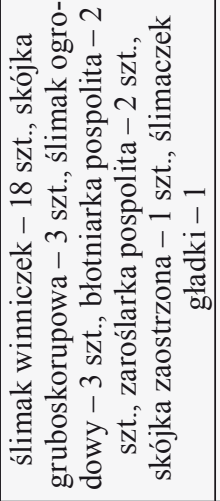 & 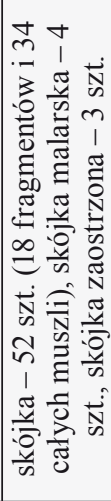 & & 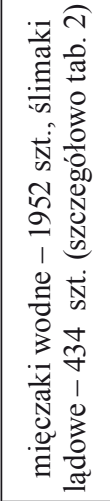 \\
\hline 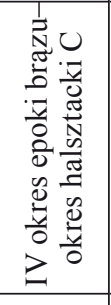 & 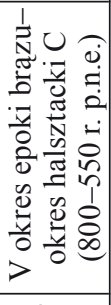 & 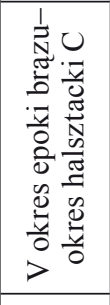 & 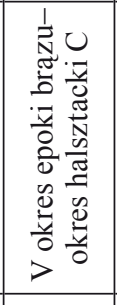 & 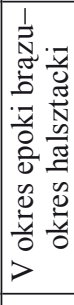 & 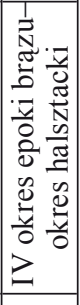 & 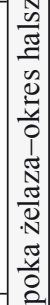 & 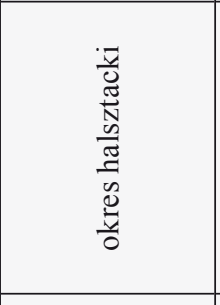 & 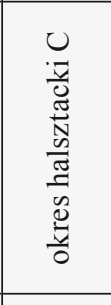 & 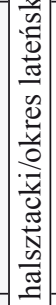 & 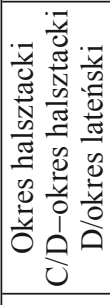 \\
\hline $\begin{array}{l}\underset{\tilde{Z}}{\tilde{Z}} \\
0 \\
0\end{array}$ & 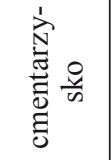 & 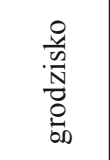 & 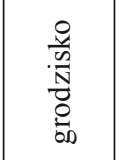 & 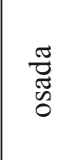 & 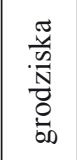 & \begin{tabular}{|c|} 
\\
$\tilde{J}$ \\
$\tilde{w}$ \\
$\tilde{N}$ \\
$\tilde{N}$ \\
3 \\
3
\end{tabular} & 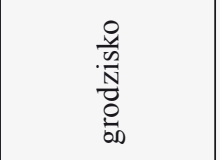 & $\begin{array}{l}\text { 莺 } \\
0 \\
0\end{array}$ & 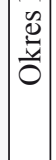 & $\begin{array}{l}0 \\
\frac{8}{y} \\
\frac{n}{N} \\
\frac{0}{0} \\
0 \\
0\end{array}$ \\
\hline 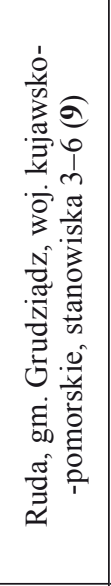 & 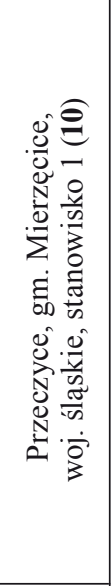 & 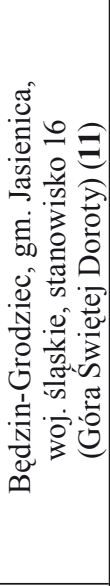 & 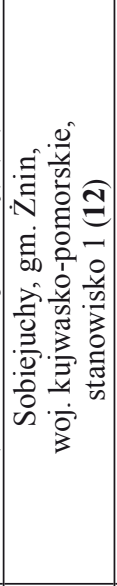 & 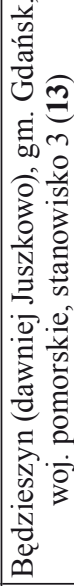 & 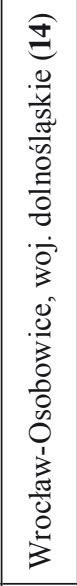 & & 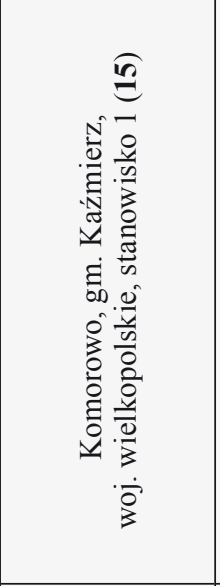 & 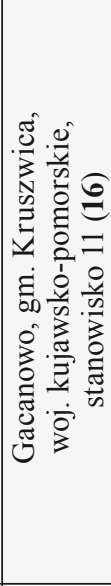 & & 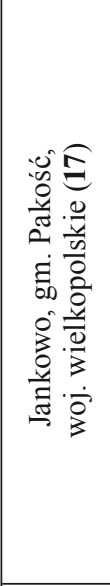 \\
\hline 은 & $=$ & $\simeq$ & $\underline{2}$ & $\Xi$ & 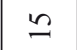 & & 느 & & & $\stackrel{\infty}{\sim}$ \\
\hline
\end{tabular}


Ryc. 3. Kamionka Nadbużna, pow. Ostrów Mazowiecki, stanowisko 1. Rzut poziomy i profil jamy gospodarczej (wg Węgrzynowicz 1968b)

Fig. 3. Kamionka Nadbużna, Ostrów Mazowiecki district, site 1. Outline and profile of the pit (according to Węgrzynowicz 1968b)
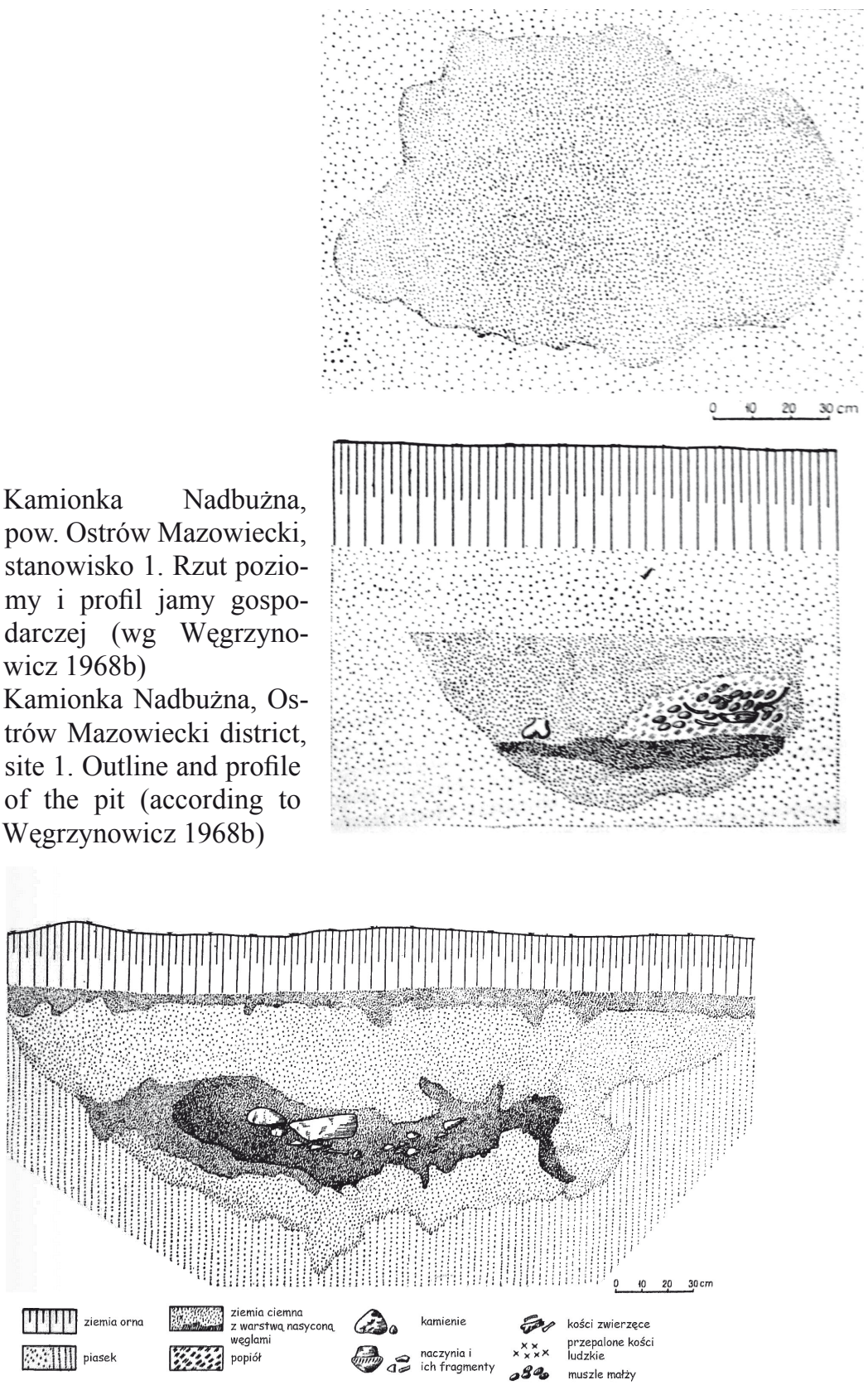

Ryc. 4. Kamionka Nadbużna, pow. Ostrów Mazowiecki, stanowisko 1. Profil jamy gospodarczej (wg Węgrzynowicz 1968b)

Fig. 4. Kamionka Nadbużna, Ostrów Mazowiecki district, site 1. Profile of the pit (according to Węgrzynowicz 1968b) 

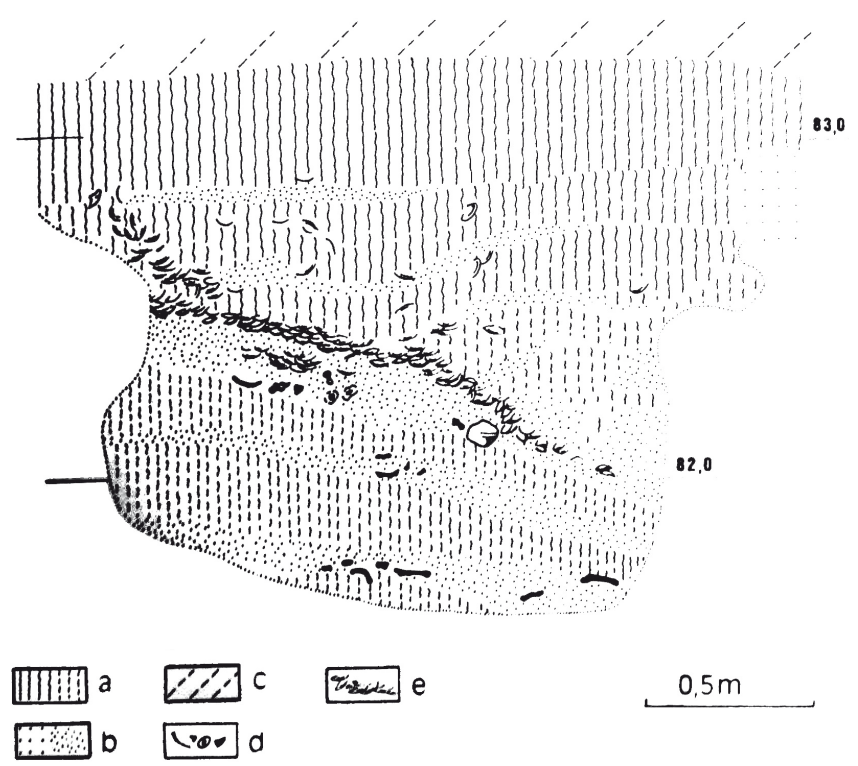

$0,5 \mathrm{~m}$

Ryc. 5. Kruszwica, pow. Inowrocław, stanowisko 4. Profil obiektu nr 10 (domniemana ziemianka) ludności kultury łużyckiej (wg Narożna-Szamałek 1986)

Fig. 5. Kruszwica, Inowrocław district, site 4. Profile of the feature no 10 (presumed dug-out dwelling) of the Lusatian culture communities (according to Narożna-Szamałek 1986)

kończyny w dolnej (Narożna-Szamałek 1986, s. 111, 114). Po drugie, warstwa z materiałem muszlowym zarejestrowana została w górnej część wypełniska omawianego obiektu, na poziomie 83,00-82,00 m n.p.m., na którym w niemalże całej południowej części osady odnotowano warstwę namułu, również zawierającą szczątki mięczaków wodnych (tab. 2). Utwory te identyfikowane są jako ślady transgresji jeziora Gopło, którą można łączyć ze zmianami klimatycznymi zachodzącymi w schyłkowej fazie okresu halsztackiego (Narożna-Szamałek 1986, s. 110). Nastąpiło wówczas zwilgotnienie klimatu i wzrost liczby opadów atmosferycznych, co spowodowało podniesienie wód jezior Gopło, Pakoskiego, Biskupińskiego i innych. Poziom Gopła wzrósł do około 83,5 m n.p.m., w jego rejonie zalane zostały terasy wyższe oraz gród kultury łużyckiej w Kruszwicy (stanowisko 1), a także niektóre osady tej kultury (datowane na okres $\mathrm{HaC} / \mathrm{HaD}-\mathrm{HaD}$ ), w obrębie których stwierdzono zaleganie warstwy akumulacyjnej ze szczątkami roślin i mięczaków wodnych (Dzieduszycki 1993, s. 136).

Interpretacja znalezisk muszli mięczaków wodnych w osadach torfowych, jako śladów wahania poziomu wód jeziornych, nie budzi większych wątpliwości 
Tabela 2. Kruszwica, woj. kujawsko-pomorskie, stanowisko K 2/4. Udział liczbowy mięczaków w obrębie wyróżnionych poziomów osadniczych (wg Narożna-Szamałek 1986)

\begin{tabular}{|l|c|c|c|c|c|}
\hline $\begin{array}{l}\text { Mięczaki } \\
\text { (Mollusca) }\end{array}$ & I Ha C & II Ha D & Pozostan. Ha & Ha C-Ha D & Razem \\
\hline $\begin{array}{l}\text { Zatoczek pospolity } \\
\text { (Planorbis planorbis) }\end{array}$ & - & - & 1 & 1 & 2 \\
\hline $\begin{array}{l}\text { Zatoczek rogowy } \\
\text { (Planorbarius corneus) }\end{array}$ & 4 & - & 2 & 6 & 12 \\
\hline $\begin{array}{l}\text { Żyworodka pospolita } \\
\text { (Viviparus contectus) }\end{array}$ & - & - & 3 & 3 & 6 \\
\hline $\begin{array}{l}\text { Błotniarka stawowa } \\
\text { (Lymnaea stagnalis) }\end{array}$ & - & - & 2 & 2 & 4 \\
\hline (Lymnaea Galba corvus) & 1 & - & - & - & - \\
\hline $\begin{array}{l}\text { Skójka gruboskorupowa } \\
\text { (Unio crassus) }\end{array}$ & 2 & 8 & 1 & 12 & 23 \\
\hline $\begin{array}{l}\text { Skójka zaostrzona } \\
\text { (Unio tumidus) }\end{array}$ & 3 & 572 & 13 & 587 & 1175 \\
\hline $\begin{array}{l}\text { Skójka malarska } \\
\text { (Unio pictorum) }\end{array}$ & - & 103 & 1 & 104 & 208 \\
\hline $\begin{array}{l}\text { Skójka } \\
\text { (Unio sp.) }\end{array}$ & 30 & 500 & 192 & 722 & 1444 \\
\hline $\begin{array}{l}\text { Szczeżuja pospolita } \\
\text { (Anodonta anatina) }\end{array}$ & - & 1 & - & 1 & 2 \\
\hline $\begin{array}{l}\text { Szczeżuja } \\
\text { (Anodonta sp.) }\end{array}$ & 4 & 110 & 2 & 116 & 232 \\
\hline $\begin{array}{l}\text { Skórkowate } \\
\text { (Unionidae) }\end{array}$ & 1 & - & 14 & 15 & 30 \\
\hline $\begin{array}{l}\text { Groszkówka } \\
\text { (Pisidium sp.) }\end{array}$ & - & 1 & - & 1231 & 2 \\
\hline Razem: & 45 & 1295 & 1571 & 3142 \\
\hline
\end{tabular}

(Alexandrowicz 1987; Tobolski 2000). W odniesieniu do obiektu nr 10 z Kruszwicy należy jednak pamiętać, że warstwa muszli obejmowała aż 1300 egzemplarzy i przykrywała pochówek. Oba fakty mogą budzić pewne wątpliwości, co do naturalnej genezy depozytu.

Większość obiektów odsłoniętych w obrębie osady w Kruszwicy datowana jest na okres halsztacki; zalegały one na tym poziomie, który odpowiadał ówczesnej strefie zalewowej jeziora Gopło (Narożna-Szamałek 1986, s. 103, tab. 1), jednak zaledwie w kilku stwierdzono obecność mięczaków. Ponadto w poszczególnych poziomach osadniczych (tab. 2), z wyjątkiem datowanego na okres $\mathrm{HaC}-\mathrm{HaD}$, odnotowano mniej muszli niż w obiekcie nr 10. Należy dodać, że dla rejonu jeziora Gopło zbieranie mięczaków datowane jest na 
okres od epoki kamienia po czasy nowożytne ${ }^{13}$ (Dzieduszycki 1993, s. 92). Szczątki malakofauny wystąpiły również w materiałach z kolejnych dwóch osad ludności kultury łużyckiej położonych nad Gopłem, z Łagiewnik (Szamałek 1987) i Gacanowa (Dzieduszycka 1977, s. 150-158) (tab. 1). Wszystkie wymienione argumenty skłaniają do uznania nagromadzenia muszli w obiekcie nr 10 z Kruszwicy (ryc. 4) za depozyt pochodzenia antropogenicznego, nie zaś naturalnego.

Nieliczne zbiory muszli pochodzą też z jamy nr 53 na osadzie ludności kultury łużyckiej w Będzieszynie (15 szt.; brak danych o przynależności gatunkowej; Podgórski 1971, s. 90) oraz z Torunia, gdzie w jamie ${ }^{14}$, datowanej na podstawie obecności charakterystycznych naczyń ceramicznych ogólnie na czas kultury łużyckiej, znaleziono jedną muszlę małży słodkowodnej (Uziembło 2003, s. 91, pozycja: 338/1).

Na pokaźny zbiór szczątków malakologicznych natrafiono w obiektach ludności kultury łużyckiej na osadzie w miejscowości Ruda ${ }^{15}$; ogółem wydobyto 122 fragmenty muszli skójki gruboskorupowej (Unio crassus), 107 skójki zaostrzonej (Unio tumidus) i 6 skójki malarskiej (Unio pictorum) (Rembisz i in. 2009, s. 115). Według autorów opracowania (Rembisz i i in. 2009, s. 119) znaczna ilość muszli mięczaków wodnych oraz obecność pozostałości żółwia błotnego, kości ryb i ptactwa wodnego w materiałach z omawianej osady świadczą o intensywnej eksploatacji strefy zalewowej, a także pobliskich jezior i oczek wodnych przez lokalną społeczność.

Dużą ilość szczeżui (Anodonta sp.) znaleziono w warstwach osadniczych z grodziska halsztackiego w Sobiejuchach (Bukowski 1959-1960, s. 214). Na ten okres są też datowane trzy połówki muszli wymienionego gatunku, znalezione w nawarstwieniach grodziska posadowionego na szczycie Góry Świętej Doroty w Grodźcu (Przybyła 2006, s. 197) oraz nieznana ilość muszli drobnych skójek z osiedla obronnego we Wrocławiu-Osobowicach (Gediga 1966, s. 72). O ile w odniesieniu do zbioru z Sobiejuch możliwa do przyjęcia jest koncepcja Z. Bukowskiego (1959-1960, s. 214)

\footnotetext{
${ }^{13}$ Liczne pozostałości muszli skójek, szczeżui oraz innych mięczaków zalegały we wczesnośredniowiecznych obiektach grodów i osad, na przykład w Mietlicy koło Kruszwicy (Klichowska 1989, s. 315-316) oraz w Kruszwicy, stanowiska 4-4a (Dzięczkowski 1966, s. 391394; 1984, s. 185-192).

${ }^{14}$ Została ona odkryta podczas ratowniczych badań archeologicznych prowadzonych w obrębie Torunia w $1970 \mathrm{r}$.

${ }^{15}$ Badania ratownicze prowadzone w pasie planowanej autostrady A1 w latach 2000-2002 przez Zespół do Badań Autostrady A1 w Instytucie Archeologii Uniwersytetu Mikołaja Kopernika w Toruniu.
} 
Tabela 3. Jankowo, gm. Pakość, woj. wielkopolskie. Liczebność szczątków mięczaków w warstwach osadniczych związanych z tzw. kulturą łużycką (wg Dzięczkowski, Ostoja-Zagórski 1976)

\begin{tabular}{|c|c|c|c|c|}
\hline $\begin{array}{l}\text { Mięczaki } \\
\text { (Mollusca) }\end{array}$ & $\begin{array}{c}\text { warstwa } \\
\mathbf{A} \\
\mathrm{Ha} \mathrm{C} / \mathrm{D}\end{array}$ & $\begin{array}{c}\text { warstwa } \\
\text { B } \\
\text { Ha D }\end{array}$ & \begin{tabular}{|c|} 
warstwa C \\
(poza wałem na \\
wschodnim brzegu \\
jeziora)
\end{tabular} & Razem \\
\hline MIĘCZAKI WODNE & 885 & 855 & 212 & 1952 \\
\hline \multicolumn{5}{|l|}{ GATUNKI MOKRADEŁ } \\
\hline Valvata pulchella & & 3 & - & \\
\hline Lymnaea (Galba) truncatula & 293 & - & 1 & \\
\hline Planorbis planorbis & - & 110 & 56 & \\
\hline Anisus spirorbis & 158 & 5 & - & \\
\hline Segmentina nitida & 13 & 25 & 10 & \\
\hline Pisidium obtusale & 2 & 5 & - & \\
\hline Pisidium casertanum & - & 3 & - & \\
\hline GATUNKI STAWÓW I JEZIOR & & & - & \\
\hline Viviparus contectus & - & 3 & 2 & \\
\hline Viviparus sp. & 3 & - & - & \\
\hline Valvata piscinalis & - & 19 & - & \\
\hline Valvata cristata & 57 & 261 & 1 & \\
\hline Bithynia tentaculata & 33 & 32 & 3 & \\
\hline Bithynia leachi & 48 & 13 & - & \\
\hline Bithynia sp. & 1 & 19 & 2 & \\
\hline Lymnaea stagnalis & 4 & 2 & 2 & \\
\hline Lymnaea (Radix) peregra & - & 1 & 1 & \\
\hline Lymnaea (Redix) sp. & - & 6 & - & \\
\hline Lymnaea (Galba) corvus & 25 & 13 & 62 & \\
\hline Lymnaea (Galba) turricula & 10 & 15 & 8 & \\
\hline Lymnaea (Galba) sp. & 31 & 75 & - & \\
\hline Lymnaea (Myxas) glutinosa & - & 1 & - & \\
\hline Lymnaeidae gen. et sp. juv. & - & 2 & - & \\
\hline Acroloxus lacustris & - & 2 & 1 & \\
\hline Planarbarius corneus & 63 & 32 & 45 & \\
\hline Planorbis sp. & 27 & 9 & - & \\
\hline Anisus vortex & 9 & 7 & 2 & \\
\hline Anisus sp. & - & - & 1 & \\
\hline Bathyomphalus contortus & 53 & 8 & 11 & \\
\hline Gyraulus albus & - & 12 & - & \\
\hline Gyraulus laevis & - & 3 & - & \\
\hline Gyraulus rossmaessleri & - & - & 2 & \\
\hline Gyraulus riparius & 12 & - & - & \\
\hline Armiger crista f. nautileus & 1 & 8 & - & \\
\hline Armiger crista f. cristatus & 3 & 2 & - & \\
\hline Armiger crista & - & 2 & - & \\
\hline Planorbidae gen. et sp. jav. & 2 & 4 & - & \\
\hline
\end{tabular}




\begin{tabular}{|c|c|c|c|c|}
\hline $\begin{array}{l}\text { Mięczaki } \\
\text { (Mollusca) }\end{array}$ & $\begin{array}{c}\text { warstwa } \\
\text { A } \\
\mathrm{Ha} \mathrm{C} / \mathrm{D}\end{array}$ & \begin{tabular}{|c} 
warstwa \\
B \\
Ha D \\
\end{tabular} & \begin{tabular}{|c} 
warstwa C \\
(poza walem na \\
wschodnim brzegu \\
jeziora)
\end{tabular} & Razem \\
\hline Unio crassus & - & 6 & \begin{tabular}{|c|}
- \\
\end{tabular} & \\
\hline Unio tumidus & - & 4 & - & \\
\hline Unio pictorum & 2 & 2 & - & \\
\hline Unio sp. & 2 & 47 & - & \\
\hline Anodonta sp. & - & 23 & - & \\
\hline Unionidae gen. et sp. juv. & - & 5 & 1 & \\
\hline Sphaerium corneum & 29 & 2 & 1 & \\
\hline Pisidium henslowanum & - & 14 & - & \\
\hline Pisidium milium & 1 & 3 & - & \\
\hline Pisidium subtruncatum & 1 & 4 & - & \\
\hline Pisidium nitidum & - & 12 & - & \\
\hline Pisidium moitessierianum & - & 3 & - & \\
\hline Pisidium sp. & 2 & 18 & - & \\
\hline ŚLIMAKI LĄDOWE & 109 & 325 & 10 & 434 \\
\hline GATUNKI LASÓW LIŚCIASTYCH & & & - & \\
\hline Clausiliidae gen. et sp. juv. & - & 3 & - & \\
\hline Clausilia bidentata & - & 1 & - & \\
\hline Carychium tridentatum & - & 11 & - & \\
\hline Acanthinula aculeata & 1 & 1 & - & \\
\hline Punctum pygmaeum & 2 & 4 & - & \\
\hline Aegopinella nitidula & 2 & 3 & - & \\
\hline Nesovitrea hammonis & 7 & 4 & 1 & \\
\hline Zonitoides nitidus & - & 10 & - & \\
\hline Helicidae gen. et sp., juv. & - & 1 & 1 & \\
\hline Arianta abustorum & 1 & - & 3 & \\
\hline Bradybaena fruticum & 2 & 4 & - & \\
\hline Euconulus fulvus & - & 1 & - & \\
\hline GATUNKI ŁĄK WILGOTNYCH & & & - & \\
\hline Carychium minimum & 15 & 44 & 4 & \\
\hline Carychium sp. & 39 & 21 & - & \\
\hline Vallonia pulchella & 4 & 60 & - & \\
\hline Vallonia costata & 3 & 32 & - & \\
\hline Vallonia sp. & 20 & 27 & - & \\
\hline Vertigo antivertigo & - & 32 & - & \\
\hline Vertigo angustior & - & 17 & - & \\
\hline Vertigo pygmaea & - & 2 & - & \\
\hline Vertigo sp. & - & 9 & - & \\
\hline Cochlicopa sp. & 4 & 3 & - & \\
\hline Succinea sp. & 8 & 34 & - & \\
\hline Oxyloma elegans & 1 & - & - & \\
\hline Trichia hispida & - & 1 & 1 & \\
\hline Razem & 994 & 1170 & 222 & 2386 \\
\hline
\end{tabular}


o wykorzystywaniu przez ludność kultury łużyckiej szczeżui jako karmy dla świnn ${ }^{16}$, to pojedyncze muszle małży wydobyte z nawarstwień pozostałych dwóch stanowisk, najprawdopodobniej znalazły się tam przypadkowo.

W materiałach archeozoologicznych z badanego w latach 1969-1972 grodziska w Jankowie na wyspie Jeziora Pakoskiego znalazły się próbki gleby pochodzące z kilku różniących się stratygraficznie poziomów osadniczych. Pod względem chronologicznym około $73,9 \%$ materiałów wydobyto z poziomu III (warstwy A-C) identyfikowanego z osadnictwem ludności kultury łużyckiej. Wśród przebadanych 51 prób, aż 46 zawierało szczątki malakologiczne (Dzięczkowski, Ostoja-Zagórski 1976, s. 321). W warstwach tych znaleziono 2386 elementów malakologicznych; przeważały szczątki mięczaków wodnych (1952 szt.), ślimaków lądowych znaleziono znacznie mniej (jedynie 434 szt.) (tab. 3). Wśród ślimaków najbogatszą w gatunki była rodzina zatoczkowych (Planorbidae), wśród małży natomiast rodzina groszkówkowatych (Sphaeriidae). Najliczniej reprezentowane były cztery pospolite gatunki ślimaków wodnych: zatoczek pospolity (Planorbis planorbis), zawójka płaska (Valvata crista), zatoczek lśniący (Segmentina nitida) i zatoczek rogowy (Planorbarius corneus) (Dzięczkowski, Ostoja-Zagórski 1976, s. 336).

Mięczaki pozyskane z warstw osadniczych na omawianym stanowisku pogrupowano według wymogów ekologicznych na: mięczaki wodne, w tym gatunki mokradeł (grupy E-8/E-10 według klasyfikacji V. Ložka 1964) oraz gatunki jezior i stawów (grupa E-11); ślimaki lądowe, w tym gatunki lasów liściastych (grupa E-1) i gatunki łąk wilgotnych (grupy E-5/E-8) (tab. 3). Typowymi przedstawicielami grupy ekologicznej mięczaków mokradeł były błotniarka moczarowa (Lymnaea (Galba) truncatula), zatoczek pospolity (Planorbis planorbis), zatoczek moczarowy (Anisus spirorbis), zatoczek lśniący (Segmentina nitida) i groszkówka pospolita (Pisidum casertanum). Wymienione zwierzęta mają fizjologiczną zdolność do okresowego przetrwania suszy, zatem ich większe nagromadzenie w próbach autorzy analizy uznali za wskaźnik granicy maksymalnego zasięgu środowiska wodnego podczas sezonowych wahań poziomu wód Jeziora Pakoskiego.

Grupę ekologiczną jezior i stawów najliczniej reprezentowały duże okazy małży z rodziny Unionidae, które żyją głównie na piaszczystym lub żwi-

\footnotetext{
${ }^{16}$ Takie interpretacje przeważały w literaturze archeologicznej w odniesieniu do znacznych ilości muszli małży znajdowanych nieraz w jamach odpadkowych na stanowiskach neolitycznych, szczególnie tych należących do wczesnej fazy kultury lendzielskiej (Hensel 1980; Jażdżewski 1981).
} 
rowym dnie zbiornika wodnego pokrytego warstwą detrytusu ${ }^{17}$ (Piechocki 1969). Pozostałe gatunki z tej grupy związane są z trwałymi eutroficznymi zbiornikami wodnymi, często silnie zarastającymi roślinnością. Ponadto zaobserwowano, że mięczaki wodne najliczniej występowały w warstwach osadniczych kultury łużyckiej związanych z młodszą fazą grodu (Dzięczkowski, Ostoja-Zagórski 1976, s. 342, 343). Takie rozmieszenie szczątków omawianych zwierząt można wiązać ze wspomnianymi już zmianami klimatu zachodzącymi pod koniec okresu halsztackiego.

Wśród zbadanych 44 próbek organicznych z warstw grodziska w Komorowie, 13 zawierało szczątki mięczaków, zarówno lądowych, jak i wodnych. W grupie ślimaków lądowych najliczniejsze były pozostałości ślimaka winniczka (Helix pomatia). Pozostałe gatunki z tej grupy ekologicznej, zidentyfikowane na podstawie kilku muszli to ślimak ogrodowy (Cepaea hortensis), zaroślarka pospolita (Bradybaena fruticum) i ślimaczek gładki (Vallonia puchella). Wśród malakofauny wodnej przeważały małże reprezentowane przez cztery muszle pochodzące od różnych osobników dwóch gatunków skójek - Unio crassus i Unio tumidus (Dzięczkowski 2004, s. 144; tab. 1). Ze ślimaków wodnych zidentyfikowano jedynie skorupki błotniarki pospolitej (Lymnaea palustris), gatunku najczęściej zasiedlającego śródleśne i śródłąkowe rowy, torfowiska, a także zalewiska ze stagnującą wodą. Wnętrza tych skorupek wypełnione były mulistym osadem, co wskazuje, że warstwa III, w której zalegały, była okresowo podtapiana wodami jeziora przy jego wysokich stanach (Dzięczkowiski 2004, s. 140). Fakt ten, wraz z małą ilością pojedynczych muszli małży znalezionych zaledwie w dwóch warstwach (III i IV) trzech wykopów (D, F i G) skłania do interpretowania omawianych materiałów malakologicznych jako pozostałości pochodzenia naturalnego, niezwiązane z działalnością człowieka.

Ostatnią kategorią stanowisk kultury łużyckiej z materiałami malakologicznymi są cmentarzyska. Muszle małży słodkowodnych znalezione zostały wśród szczątków ludzkich w czterech grobach ciałopalnych bezpopielnicowych na dwóch cmentarzyskach - w Kamionce Nadbużnej (groby nr 60 i 76; Węgrzynowicz 1968a, s. 221, 224, 242) oraz Przeczycach (groby 227 i 258; Szydłowska 1972, s. 160). W grobie nr 60 z Kamionki Nadbużnej zidentyfikowano ułamki muszli szczeżui (Anodonta sp.), a w grobie 76 skójki (Unio sp.). Ze względu na zły stan zachowania muszli z cmentarzyska w Przeczycach, nie okreslono do jakich gatunków należały wydobyte

\footnotetext{
${ }^{17}$ Osad biogeniczny powstały między innymi ze szczątków obumarłych organizmów roślin-
} nych i zwierzęcych. 
fragmenty. Ustalono natomiast, że w pierwszym grobie pochowano dziecko, prawdopodobnie sześciomiesięczne, $\mathrm{w}$ drugim zaś mężczyznę około 18-letniego (Szydłowska 1972, s. 160).

Na cmentarzysku z młodszej epoki brązu w miejscowości Nowy Łowicz $^{18}$, pod kamieniami wieńca u podstawy nasypu kurhanu $23^{19}$ natrafiono na jamę wypełnioną prawie w całości muszlami małży (Hahuła 1992, s. 55, ryc. 2). Jama ta zawierała również naczynia ceramiczne kultury łużyckiej i kości zwierzęce (Hahuła 1992, s. 54). Nowe badania materiałów malakologicznych wydobytych z omawianej jamy nasunęly ich autorom przypuszczenie, że stanowiła ona magazyn muszli, które miały być wykorzystane do wyrobu ozdób (Kurzawska 2008, s. 60). W jamie tej nie znaleziono jednak gotowych wyrobów (np. paciorków), półproduktów czy narzędzi, które przemawiałyby za taką genezą depozytu.

Jeden egzemplarz muszli małży nieoznaczony gatunkowo pochodzi również z cmentarzyska w Brzegach ${ }^{20}$. Przypuszczalnie pierwotnie zdeponowany był w jednym $z$ obecnie zniszczonych grobów popielnicowych. Miał on wywiercony otwór, co może wskazywać, że stanowił on pewnego rodzaju naszyjnik czy zawieszkę (Miśkiewicz 1968, s. 158).

Stosowanie ozdób wykonanych z muszli z otworami może także poświadczać znalezisko takiego egzemplarza pochodzące ze skarbu w miejscowości Żydów ${ }^{21}$ (Żurowski 1922, s. 88, tabl. II; ostatnio Blajer 2001, s. 328, nr 84) oraz wspominany już depozyt 15 muszelek z Będzieszyna (Podgórski 1971, s. 90). Według opublikowanych danych wszystkie muszle miały otwory i mogły wchodzić w skład jednego naszyjnika.

Jak wskazują dane etnograficzne muszle małży występujących w polskich rzekach i jeziorach mogły być wykorzystywane jako surowiec do produkcji ozdób (np. wspomnianych guzików). Jednak bark opublikowanej dokumentacji rysunkowej i fotograficznej wymienionych wyżej okazów z otworami

\footnotetext{
${ }^{18}$ Znajdowało się ono na skraju południowo-zachodniej części cmentarzyska kurhanowego z okresu wpływów rzymskich.

${ }^{19}$ Pod kurhanem znajdował się centralnie usytuowany pochówek szkieletowy, najpewniej dziecka, wyposażony między innymi w część bransolety ze żmijowatą główką.

${ }^{20}$ Duże cmentarzysko, liczące około 60 grobów ciałopalnych popielnicowych, było eksplorowane w amatorski sposób, profesjonalnie przebadano zaledwie kilka grobów. Większość obiektów nie ma odpowiedniej dokumentacji, co znacznie obniża ich wartość poznawczą (Miśkiewicz 1968, s. 160).

${ }^{21}$ Skarb umieszczony był w obstawie kamiennej, w glinianym naczyniu, poza muszlą zawierał parę naramienników z tarczkami, 5 bransolet, 12 tarczkowatych guzków z uszkiem, 127 spiralnych rureczek, 10 paciorków bursztynowych, 2 paciorki szklane. Przedmioty te znajdują się obecnie w Muzeum Archeologicznym w Krakowie.
} 
skłania jedynie do przypuszczenia, że otwory rzeczywiście wykonane zostały przez człowieka w celu dostosowania muszli do funkcji dekoracyjnej.

Jak wynika z przytoczonych danych, w materiałach malakologicznych z badań wykopaliskowych najliczniej reprezentowane są małże z rodziny skójkowatych (Unionidae), przede wszystkim różne skójki, rzadziej szczeżuje. Gatunki te występują powszechnie w czystych wodach, na piaszczystym lub żwirowym dnie jezior i rzek. Muszle dużych osobników, przykrytych warstwą detrytusu, ludność kultury łużyckiej wyławiała zapewne rękoma z przybrzeżnych części zbiorników wód słodkich. Obecność w śmietnisku muszlowym z osady ludności wspomnianej kultury w miejscowości Lutol Mokry szczątków drobnych gatunków ślimaków i małży, wielkością nieprzekraczających $1 \mathrm{~cm}$, oraz mniejszych osobników Unio sp. i Anadoota sp., być może wskazuje na zastosowanie innej metody zbierania mięczaków (drobne osobniki o niekonsumpcyjnej wielkości są pomijane przy zbieraniu ręcznym) (Kurzawska 2008, s. 60). Prawdopodobnie posługiwano się wówczas pewnymi formami pojemników - koszy, tak jak miało to miejsce w Polsce jeszcze w połowie XX wieku.

Zaprezentowana wyżej różnorodność depozytów muszlowych otwiera przed badaczem (archeologiem, archeozoologiem) szereg możliwości interpretacyjnych. Z jednej strony mamy bowiem przesłanki wskazujące na gospodarcze użytkowanie mięczaków w celach konsumpcyjnych, zarówno dla ludzi, jak i zwierząt hodowanych. Z drugiej natomiast, nie możemy wykluczyć, że zainteresowanie człowieka budziły same muszle. Mogły one być stosowane jako surowiec do wyrobu narzędzi, przedmiotów codziennego użytku, różnego rodzaju ozdób, również amuletów czy talizmanów. Jako takie mogły wiązać się z pewnymi wierzeniami oraz zabiegami magicznymi.

O zbieraniu i wykorzystywaniu małży słodkowodnych jako pożywienia dla ludzi lub zwierząt, można wnioskować na podstawie depozy tów ich muszli z jam paleniskowych odkrytych w Kamionce Nadbużnej i Kruszwicy. Małże poddawano obróbce termicznej, co powodowało ich uśmiercenie i otwarcie muszli, a w efekcie wydobycie jej miękkiej zawartości stanowiącej źródło cennych składników odżywczych. Na skarmianie małżami słodkowodnymi zwierząt hodowlanych może wskazywać fakt, że w niektórych regionach Polski (np. na Kaszubach, w rejonie jeziora Wdzydze) jeszcze w latach 50. minionego wieku karmiono małżami (skójkami i szczeżujami) świnie, kaczki i kury. Mięczaki gotowano w całości, następnie wydobytym z muszli mięsem karmiono zwierzęta (ten rodzaj pokarmu nazywano żabianką), a wywar (rosół) podawano im do picia (Kawecki 1988, s. 205). Poprzez gotowanie mięso małży staje się 
również przyswajalne dla człowieka. „W przypadku omawianych gatunków małży słodkowodnych nie stwierdzono jedzenia ich na surowo" (Kurzawska 2008, s. 59). Innym sposobem przygotowania mięsa tych zwierząt do spożycia, stosowanym przypuszczalnie w przypadku konsumpcji przez człowieka, było pieczenie na ogniu (względnie prażenie). Mogą na to wskazywać między innymi znaleziska muszli małży zalegających w warstwie spalenizny lub nadpalonych pochodzące z miejscowości Lutol Mokry (Kurzawska 2008, s. 60).

Ze względu na niską kaloryczność i małą zawartość białka małże raczej nie odgrywały znaczącej roli w diecie ludzi, gdy pod dostatkiem było mięsa, na przykład dużych ssaków. Jednakże dzięki zawartości minerałów takich jak żelazo, fosfor i wapń, mogły one zastąpić wysokokaloryczne pokarmy w okresach niedoboru żywności zarówno dla ludzi, jak i zwierząt (chociażby na tzw. przednówku) lub stanowić jego uzupełnienie (Kurzawska 2008, s. 60) czy urozmaicenie. Być może mięczaki jadano ze względu na walory smakowe. Do dziś między innymi na terenie Wielkopolski zbierane są ślimaki winniczki (Dydowiczowa 1964, s. 315). Choć obecnie przeznacza się je głównie na eksport do Francji, gdzie stanowią prawdziwy przysmak, to dysponujemy danymi etnograficznymi potwierdzającymi jadanie ślimaków również w Polsce - „W styczniu najlepsze są ślimaki, kto je rad je” (Zawacki 1616, s. 64).

Jak wyżej wspomniano, w interpretacji depozytów muszlowych należy uwzględnić możliwość magiczno-symbolicznego znaczenia malakofauny w wierzeniach ludności kultury łużyckiej. Pośrednio w zrozumieniu znaczenia mięczaków w sferze duchowej mogą pomóc analogie z innych kręgów kulturowych. Ostrygi, muszle morskie i śródlądowe, ślimaki oraz perły w wielu kulturach należą zarówno do kosmologii akwatycznych, jak i do sfery seksualnej. Muszle licznych gatunków mięczaków, ze względu na swoje podobieństwo do organów płciowych kobiety, uznawane są za ochronę przed wszelką magia. Naszyjniki z muszli, bransolety, amulety zdobione muszlami czy nawet tylko ich wizerunkami, chronią kobiety, dzieci i zwierzęta domowe przed urokami, chorobami, bezpłodnością itd. (Eliade 1998, s. 158). „Wiara w magiczną moc ostryg i muszli rozpowszechniona jest na całym świecie, od prehistorii po czasy nowożytne" (Eliade 1998, s. 147). Symbolizm ten ulegał jednak kolejnym „uwspółcześnieniom” i rozmaitym interpretacjom; ostrygi i inne mięczaki obecne są w obrządkach agrarnych, weselnych lub pogrzebowych, w ozdobach ubiorów (np. stroje góralskie) i w niektórych motywach dekoracyjnych, nawet jeśli nieraz wydaje się, że ich magiczno-religijne znaczenie zatarło się w zderzeniu z nową rzeczywistością (Eliade 1998, s. 148). Do dziś przecież ostrygi uchodzą za silny afrodyzjak. 
Znaczna ilość mięczaków, muszli morskich i słodkowodnych, pereł prawdziwych i sztucznych pochodzi z siedliskach prahistorycznych, przede wszystkim z grobów (Eliade 1998, s. 160, 161). Muszle z Morza Czarnego znaleziono w grobach egipskich z okresu przeddynastycznego; przez długi czas muszle służyły Egipcjanom jako amulety. Wyniki badań archeologicznych na Krecie wskazują, że również tam muszle i mięczaki były powszechnie używane. Na znanym cmentarzysku Kubania w północnej części Kaukazu (XIV wiek p.n.e.) natrafiono na Cypraea moneta, zaś na muszle innych mięczaków w grobach z okolicy Kijowa, należących do kultury Alanino z zachodniego Uralu. Istnienie analogicznych zbiorowisk stwierdzono również w Bośni, Anglii, we Francji i w Niemczech, szczególnie na wybrzeżach Morza Bałtyckiego (Eliade 1998, s. 164).

W przypadku ziem polskich, już w sferze wierzeń populacji mezolitycznych mógł zaistnieć symbol muszli. Może na to wskazywać najstarsze znalezisko muszli z Janisławic, pow. Skierniewice (Hensel 1980, s. 34; Dzięczkowski 1998, s. 100), gdzie w wyposażeniu grobu szkieletowego ${ }^{22}$ rozpoznano kilka fragmentów muszli skójki zaostrzonej (Unio tumidus). Zbieranie znacznych ilości tych małży, na przykład skójki malarskiej (Unio pictorum) oraz stosowanie ich muszli do wyrobu naszyjników lub wisiorków odnotowano u wczesnych społeczności rolniczych neolitycznego cyklu ceramiki wstęgowej rytej (Czerniak 1980, s. 102, ryc. 35; Jażdżewski 1981, s. 190). Duże ilości muszli małży i ślimaków znane są z grobów ludności młodszych kultur kręgu naddunajskiego. Niekiedy ich liczba dochodziła nawet do kilkuset sztuk, co wyklucza możliwość naturalnego pochodzenia depozytów. Ponadto na stanowiskach kultury lendzielskiej kilkukrotnie natrafiono na wisiorki lub paciorki z muszli między innymi małża (Spondylus gaederopus), zapewne importowanych z krajów wschodniośródziemnomorskich (Hensel 1980, s. 60). Zjawisko to, odnotowane również na stanowiskach z Czech, może świadczyć o cenieniu muszli ze względu na walory estetyczne, a być może także magiczno-symboliczne. Sprowadzane z południa muszle pochodzą też z młodszych chronologicznie materiałów. W grobach kultury pomorskiej z Pomorza Wschodniego, datowanych na połowę $\mathrm{V}$ wieku p.n.e., często natrafiano na muszle Cypraea, znane z literatury jako ślimaki kauri, docierające na ziemie polskie z krajów nad Morzem Czerwonym, Zatoką Perską czy Oceanem Indyjskim (Bukowski 2005, s. 57). Uznaje się je za wyznacznik rozpowszechnienia się

\footnotetext{
${ }^{22}$ Był to pochówek mężczyzny w wieku około 30-40 lat. Oprócz wspomnianych muszli wyposażenie stanowiło 41 wyrobów krzemiennych, 54 przedmioty z kości rogu/poroża (w tym 43 obrobione) - między innymi kolię złożoną z 20 przedziurawionych siekaczy oraz kilku kłów jelenia (Hensel 1980, s. 34, 35).
} 
w tym czasie kultu żeńskiego bóstwa płodności (Dzięczkowski 1998, s. 101). Z grobów kultury oksywskiej, między innymi z Kruszwicy, znane są okazałe wisiorki sporządzane $\mathrm{z}$ tych muszli.

Być może podobnie postrzegała muszle mięczaków ludność kultury łużyckiej. Nie dysponujemy jednak bezpośrednimi dowodami na ich symboliczne znaczenie. Opisane depozyty z jednej strony stanowią podstawę do stwierdzenia, że ludność wspomnianej kultury zajmowała się zbieractwem mięczaków, z drugiej zaś do analizy znaczenia mięczaków wodnych w pozautylitarnej strefie życia ludzkiego. Znaleziska szczątków malakologicznych w grobach mogą wskazywać na użytkowanie muszli w celach dekoracyjnych, o znaczeniu czysto estetycznym, jak również na obecność pewnej symboliki, na przykład w kultach chtonicznych. Jeżeli natomiast przyjmiemy, że małże słodkowodne wykorzystywane były przez ludność kultury łużyckiej jako pokarm, to należałoby traktować je tak samo jak kości zwierząt kręgowych.

Niestety, na obecnym etapie badań depozytów muszlowych ze stanowisk kultury łużyckiej nie można jednoznaczne stwierdzić czy symbol muszli obecny był w „wierzeniach” omawianych społeczności. Wyraźniej zaznaczają się w materiale archeologicznym przesłanki wskazujące na gospodarcze użytkowanie mięczaków, w celach konsumpcyjnych dla ludzi i dla zwierząt hodowlanych. Pamiętać należy, że również depozyty szczątków malakofauny o pochodzeniu naturalnym, nie związanym z celową działalnością człowieka, stanowią niezmiernie cenne źródło informacji dla archeologów. W połączeniu z aktualną wiedzą na temat zróżnicowania biologicznego i wymagań ekologicznych poszczególnych przedstawicieli typu Mollusca, moga one pomóc w interpretacji lokalnych warunków środowiskowych panujących w przeszłości. Jak pokazano powyżej, z próbą takiego zastosowania obecności materiałów malakologicznych na stanowiskach kultury łużyckiej mamy do czynienia przynajmniej dwukrotnie, w Jankowie (Dzięczkowski, Ostoja-Zagórski 1976, s. 319-353) i Komorowie (Dzięczkowski 2004, s. 139-146). Wobec upowszechniającego się $\mathrm{w}$ archeologii podejścia przyrodniczego spodziewać się można kolejnych tego rodzaju opracowań. Przyszłe badania i szczegółowe analizy depozytów muszlowych oraz kontekstów ich występowania na stanowiskach kultury łużyckiej przyniosą zapewne nowe możliwości interpretacyjne. 


\section{Podsumowanie}

Niniejszy artykuł nie wyczerpał całkowicie zagadnień związanych ze zbieractwem mięczaków w pradziejach. Nie to było jednak jego zadaniem, bowiem $\mathrm{w}$ przeprowadzonych rozważaniach wykorzystano przede wszystkim wyniki opublikowanych analiz szczątków mięczaków odkrytych w kontekstach archeologicznych kultury łużyckiej. Za ich pomocą zaprezentowano rodzaje depozytów muszlowych na stanowiskach tej kultury z ziem polskich.

Z przytoczonych danych wynika, że w materiałach z badań wykopaliskowych najliczniej reprezentowane są małże z rodziny skójkowatych (Unionidae), przede wszystkim różne skójki. Najprawdopodobniej były one zbierane na pokarm dla zwierząt hodowanych oraz dla ludzi, na co wskazuje charakter niektórych obiektów z muszlami. Przypuszczalnie przyszłe odkrycia depozytów muszlowych oraz analizy malakologiczne pomogą w określeniu miejsca zbieractwa mięczaków w cyklu całorocznych zajęć omawianych społeczności, co nie jest możliwe przy obecnym stanie badań.

Konieczne jest nowe podejście do materiałów malakologicznych wydobywanych z kontekstów archeologicznych. Systematyczne badania szczątków mięczaków mogą bowiem pomóc we wnioskowaniu na temat charakteru paleośrodowiska oraz warunków klimatycznych stanowiska i jego okolic.

\section{LITERATURA}

Wykaz skrótów

SA - Sprawozdania Archeologiczne, Warszawa

Alexandrowicz S. W.

1983 Malocofauna of the Holocene calcareous sediments of the Cracow Upland, Acta Geologica Polonica, t. 33, z. 1-4, s. 117-158.

1984 Zespoty mięczaków rezerwatu Obrożyska koto Muszyny, Chrońmy przyrodę ojczysta, t. 40, z. 4, s. 40-47.

1987 Analiza malakologiczna w badaniach osadów czwartorzędowych, Zeszyty Naukowe Akademii Górniczo-Hutniczej, Geologia, t. 12, z. 1-2, Kraków.

1996 Malakofauna i zróżnicowanie środowiska naturalnego, [w:] J. Kruk, S. Milisauskas, S. W. Alexandrowicz, Z. Śnieszko, Osadnictwo i zmiany 
środowiska naturalnego wyżyn lessowych. Studium archeologiczne $i$ paleogeograficzne nad neolitem $w$ dorzeczu Nidzicy, Kraków, s. 73-94.

Ant $\mathrm{H}$.

Malakologische Funde bei den Ausgrabungen und ihre Bedeutung für die Archäologie, Reinische Ausgrabungen, t. 10, s. 449-466.

Barga-Więcławska J. A.

2009a Mięczaki podstawa rekonstrukcji zmian środowiska przyrodniczego wywołanych gospodarka człowieka w neolicie na Wyżnie Sandomierskiej, [w:] Zapis działalności człowieka w środowisku przyrodniczym. VII Warsztaty terenowe. IV Sympozjum Archeologii Środowiskowej, 20-22.05.2009, Kórnik, red. I. Hildebrandt-Radke, J. Jasiewicz, M. Lutyńska, Środowisko i kultura, t. 6, Poznań, s. 26-29.

2009b Wyniki wstęnych badań do monitoringu malakofauny zlewni „Pożary” w Kampinoskim Parku Narodowym, [w:] Raport o stanie środowiska przyrodniczego zlewni Zintegrowanego Monitoringu Środowiska Przyrodniczego „Pożary” w 2008 roku, Kampinoski Park Narodowy, Gminy, s. 131-154 (kampinoski-pn.gov.pl/monitoring/2008/10A_slimaki_2008d.pdf).

Barga-Więcławska J. A., Czerwik-Marcinkowski J., Mrozińska-Broda T.

2002 Monitoring przestrzeni pohutniczej zespotu wielkopiecowego w Starachowicach z wykorzystaniem glonów i ślimaków jako biowskaźników stanu środowiska przyrodniczego, Regionalny Monitoring Środowiska Przyrodniczego, nr 3, s. 71-74.

Blajer W.

Skarby przedmiotów metalowych z epoki brqzu i wczesnej epoki żelaza na ziemiach polskich, Kraków.

Boss K.

1971 Critical estimate of the number of recent Mollusca, Museum of Comparative Zoology, Harvard University. Occasional Papers on Mollusks 3(40), s. 81-135.

Bukowski Z.

1959-1960 Łużyckie osiedle obronne w Sobiejuchach, pow. Żnin, Wiadomości Archeologiczne, t. 26, z. 3-4, s. 194-224.

2005 Bursztyn a kontakty Pomorza Wschodniego we wczesnej epoce żelaza, [w:] Aktualne problemy kultury pomorskiej, red. M. Fudziński, H. Paner, Gdańsk, s. 45-64.

Czerniak L.

1980 Rozwój spoteczeństw kultury późnej ceramiki wstęgowej rytej na Kujawach, Poznań.

Dydowiczowa J.

1964 Zbieractwo, [w:] Kultura ludowa Wielkopolski, t. 2, red. W. Burszta, Poznań, s. 299-327. 
Dzieduszycka B.

1977 Rejestr stanowisk archeologicznych $w$ rejonie Jez. Gopla, woj. Bydgoszcz, Fontes Archaeologici Posnanienses, t. 26, s. 150-158.

Dzieduszycki D.

1993 Człowiek, [w:] Gopło. Przyroda i człowiek, red. W. Dzieduszycki, M. Kupczyk, Poznań, s. 79-162.

Dzięczkowski A.

1966 Szczatki zwierzęce $z$ wykopalisk archeologicznych w Kruszwicy, pow. Inowroctaw, z lat 1959-1962, SA, t. 18, s. 391-394.

1969 Mięczaki w próbach z wykopalisk w 1962 roku na Rynku Warzywnym w Szczecinie, SA, t. 20, s. 445-447.

1974a Subfosylne szczqtki mięczaków (Mollusca) i roślin ze stanowiska 1 w Otalażce, pow. Grójec, Archeologia Polski, t. 19, z. 2, s. 379-386.

1974b Subfosylne mięczaki (Mollusca) z osadów nad Jeziorem Czeszewskim pod Smuszewem, pow. Wagrowiec, Badania Fizjograficzne nad Polską Zachodnią, t. 27, Seria C - Zoologia, Poznań-Warszawa, s. 113-116.

1975 Badania ilościowe mięczaków i ich znaczenie dla różnych dziedzin wiedzy, [w:] Prace Komisji Naukowych Polskiego Towarzystwa Gleboznawczego III, z. 16, Materiały z I Sympozjum Zoologów Gleby Rogów, 25-26 marca 1974, Warszawa, s. 133-142.

1984 Mięczaki (Mollusca) z wykopalisk archeologicznych w Kruszwicy na stanowisku 4 i 4a, SA, t. 36, s. 185-192.

1988 Zespoły ślimaków (Gastropoda) zbiorowisk leśnych Polski. Studium ekologiczne, Warszawa-Poznań.

1998 Badania malakologiczne w archeologii, [w:] Nauki przyrodnicze i fotografia lotnicza w archeologii, red. W. Śmigielski, Poznań, s. 97-110.

2004 Materiaty malakologiczne i botaniczne, [w:] Komorowo stanowisko 1. Grodzisko kultury tużyckiej i osadnictwo wczesnośredniowieczne. Badania specjalistyczne, red. T. Malinowski, Zielona Góra, s. 139-146.

Dzięczkowski A., Ostoja-Zagórski J.

1976 Próba zastosowania analizy malakologicznej do rekonstrukcji środowiska przyrodniczego na przykładzie grodziska halsztackiego z Jankowa, woj. Bydgoszcz, Archeologia Polski, t. 21, z. 2, s. 319-353.

Dzik J.

1992 Dzieje życia na Ziemi. Wprowadzenie do paleobiologii, Warszawa.

Eliade M.

1998 Obrazy i symbole. Szkice o symbolizmie magiczno-religijnym, Warszawa.

Encyklopedia

2007 Encyklopedia powszechna PWN, A-M, Warszawa.

Evans J. G.

1969 Land and Freshwater Mollusca in Archaeology: Chronological Aspect, World Archaeology, t. 1, nr 2, s. 170-183.

1972 Land snails in archaeology, London. 
Falniowski A.

2001 Drogi i bezdroża ewolucji mięczaków, Kraków.

Friedberg W.

1934 Coquilles des mollusques dans un tombeau néolothique á Złota prés de Sandomierz (Pologne), Journal de Conchyliologie, t. 78(2), s. 91-97.

Gediga B.

1966 Wyniki badań wykopaliskowych na osiedlu obronnym kultury tużyckiej we Wrocławiu-Osobowicach w 1964 roku, SA, t. 18, s. 67-72.

Hahuła K.

1992 Dalsze badania w Nowym Łowiczu. Kurhan 63, Koszalińskie Zeszyty Muzealne, t. 19, s. 53-68.

Hensel W.

1980 Polska starożytna, Wrocław.

Jażdżewski K.

1981 Pradzieje Europy Środkowej, Wrocław.

Jura Cz.

1971 Bezkręgowce. Morfologia, systematyka, filogeneza, Warszawa-Kraków.

1996 Bezkręgowce. Podstawy morfologii funkcjonalnej, systematyki i filogenezy, Warszawa.

Kawecki Z.

1988 Zoologia stosowana, Warszawa.

Klichowska M.

1989 Wyniki badań paleobotanicznych próbek ze stanowisk 1 i 3 z Mietlicy, woj. Bydgoszcz z 1977 i 1979 r., SA, t. 40, s. 315-316.

Kowalkowski A., Berger L.

1965 Subfosylna malakofauna jako wskaźnik pedogenezy w holocenie, Roczniki Gleboznawcze, t. 15, s. 443-448.

1966 Zastosowanie metody paleomalakologicznej do badań nad rozwojem gleb w holocenie, Folia Quaternaria, nr 23, s. 27.

Kozłowski J. K.

2004 Świat przed „rewolucja” neolityczna, [w:] Wielka Historia Świata, t. 1, Kraków.

Kruk J., Milisauskas S., Aleksandrowicz S. W., Śnieszko Z.

Osadnictwo i zmiany środowiska naturalnego wyżyn lessowych. Studium archeologiczne i paleogeograficzne nad neolitem $w$ dorzeczu Nidzicy, Kraków.

Kurzawska A.

2008 Śmietniska muszlowe na terenie Polski, [w:] Badania archeozoologiczne w Polsce i Europie Środkowo-wschodniej. Materiaty - Metody - Interpretacje. III Sympozjum Archeologii Środowiskowej, Katowice-Koszęcin 26-29 listopada 2008, red. D. Makowiecki i in., Środowisko i Kultura, t. 5, Poznań, s. 59-63.

Ložek V.

1964 Quartärmollusken der Tschechoslowakei, Rozpravy Ústředniho Ústavu Geologického, nr 31, s. 374. 
Depozyty ze szczątkami mięczaków na stanowiskach kultury łużyckiej...

1967 Beiträge der Molluskenforschung zur prähistorischen Archäologie Mitteleuropas, Archäologische Zeitschrift, t. 1, s. 88-138.

Makowiecki D., Makowiecka M.

2004 Zwierzęce szczatki kostne, [w:] Komorowo stanowisko 1. Grodzisko kultury tużyckiej i osadnictwo wczesnośredniowieczne. Badania specjalistyczne, red. T. Malinowski, Zielona Góra, s. 19-92.

Miśkiewicz J.

1968 Kultura tużycka w międzyrzeczu Pilicy i środkowej Wisty, Materiały Starożytne, t. 11, s. 129-208.

Molluscs

2008 Molluscs and other marine resources, Archaeofauna, International Journal of Archaeozoology, t. 17, red. K. Szabo, I. Quitmyer, Madrid.

Narożna-Szamałek U.

1986 Osada ludności kultury tużyckiej w Kruszwicy, stan. K-2/4, Fontes Archaeologici Posnanienses, t. 35, s. 103-132.

Piechocki A.

1969 Obserwacje biologiczne nad matżami z rodziny Unionidae $w$ rzece Gobi, Acta Hydrobiologia, t. 11, nr 1, s. 57-67.

1971 Szczatki mięczaków z cmentarzyska kultury pucharów lejkowatych na stanowisku 1 w Sarnowie, pow. Włocławek, z grobowca 8, Prace i Materiały Muzeum Archeologicznego i Etnograficznego w Łodzi, seria archeologiczna, nr 18, s. 131-138.

1979 Mięczaki (Mollusca), ślimaki (Gastropoda), Fauna Słodkowodna Polski, z. 7, Warszawa-Poznań.

1989 The Sphaeriidae of Poland. Bivalvia, Eulamellibranchia, Annales Zoologici, t. 42, nr 12, s. 249-320.

Podgórski J. T.

1971 Z badań wykopaliskowych w Juszkowie (Będzieszynie), w pow. gdańskim (1967-1969), SA, t. 23, s. 79-91.

Przybyła M. M.

2006 Materiaty z osady obronnej kultury tużyckiej na Górze Świętej Doroty w Będzinie-Grodźcu, [w:] Z badań nad osadnictwem epoki brazu $i$ wczesnej epoki żelaza w Europie Środkowej, red. W. Blajer, Kraków, s. 181-202.

Reese D. S., Mienis H. K., Woodward F. R.

1986 On the Trade of Shells and Fish from the Nile River, Bulletin of the American Schools of Oriental Research, nr 264, s. 79-84.

Rembisz A., Gackowski J., Makowiecki D., Markiewicz M., Polcyn M.

2009 Ślady gospodarki roślinno-zwierzęcej ludności kultury tużyckich pól popielnicowych z osady w Rudzie, gmina Grudziqdz, pótnocna Polska, [w:] Środowiskowe uwarunkowania lokalizacji osadnictwa, red. L. Domańska, P. Kittel, J. Forysiak, Środowisko - Człowiek - Cywilizacja, t. 2, Poznań, s. 109-122. 
Riedel A.

1988 Ślimaki ladowe. Gastropoda terrestria, Katalog Fauny Polskiej, t. 36, z. 1, Warszawa.

Riedel A., Pokryszko B. M.

1999 Malakologia polska. Historia-Stan Obecny-Perspektywy, Poznań.

Skompski S.

Sparks B. W.

Fauna czwartorzędowa Polski. Bezkręgowce, Warszawa.

Non-Marine Mollusca and Archaeology, [w:] Science in archaeology,

Szamałek K. red. D. Brothwell, E. Higgs, Bristol, s. 313-323.

Kruszwicki zespół osadniczy w młodszej epoce brqzu i poczatkach żela$z a$, Wrocław.

Starmach K.

1976 Jeziora, [w:] Hydrobiologia. Limnologia, red. K. Starmach, S. Wróbel,

K. Pasternak, Warszawa, s. 326-424.

Szydłowska E.

1972 Cmentarzysko kultury tużyckiej w Przeczycach, pow. Zawiercie, Roczniki Muzeum Górnośląskiego w Bytomiu, Archeologia, z. 9.

Tobolski K.

2000 Przewodnik do oznaczania torfów i osadów jeziornych, Warszawa.

Urbański J.

1932 Przyczynek do znajomości mięczaków z międzyladowych trawertynów z Gliczarowa pod Zakopanem, Roczniki Polskiego Towarzystwa Gleboznawczego, t. 8, z. 2, s. 205-209.

1935 Fauna mięczaków (Mollusca) kredy jeziornej, Starunia, nr 8, s. 8-11.

1957 Mięczaki osadów holocenu w Żuchowie koło Karnkowa, Biuletyn Instytutu Geologicznego, t. 118, s. 231-266.

1977 Mięczaki, Studia Naturae, Seria B, t. 28, s. 299-318.

Uziembło R.

2003 Rejestr stanowisk archeologicznych $i$ znalezisk z terenu Torunia, Toruń. Węgrzynowicz T.

1968a Cmentarzysko kultury łużyckiej w Kamionce Nadbużnej, pow. Ostrów Mazowiecki, Materiały Starożytne, t. 11, s. 209-248.

1968b Łużycki zespół osadniczy z okolic Nura w pow. Ostrów Mazowiecki, [w:] Szkice z najdawniejszej przeszłości Mazowsza, red. W. Hensel, Wrocław, s. 44-59.

Wiktor A.

1965 Fauna ślimaków, [w:] Badania osadów schroniska w Puchaczej Skale w Pradniku Czajowskim, pow. Olkusz, red. K. Kowalski, J. K. Kozłowski, M. Krysowska, Folia Quaternaria, nr 20, s. 28-37.

2004 Ślimaki ladowe Polski, Olsztyn.

Zawacki T.

1616 Memoriale occonomicum, Kraków. 
Żurowski J.

1922 Skarb brazowy z Żydowa, Wiadomości Archeologiczne, t. 7, s. 78-145.

\section{MOLLUSCS REMAINS DEPOSITS FROM LUSATIAN CULTURE SITES IN POLAND. CHARACTERIZATION AND ATTEMPT TO DETERMINE THE ORIGIN OF DEPOSITS}

\section{Summary}

For communities of Lusatian culture (the III Bronze Age period - the beginning of the Early La Téne), which occupied Polish lands, one of the basic way of the environment exploitation it was gathering of various plants, small vertebrates and also molluscs.

The article contain collected from the literature data of molluscs remains, which have been found at aforementioned culture sites. They were used to characterize shells aggregations and to make an attempt to determine their origin at archaeological sites. Furthermore usefulness of molluscs in reconstruction of the former environment and its changes, and also as a bio-informants of human activities have been shown.

A documented diversity of shells deposits allowed the author to make several interpretations. There are reasonable grounds to conclude that some of aggregations have been caused by subsistence economic activities of communities of Lusatian culture (e.g. Kamionka Nadbużna, site 1). Molluscs could be eaten by human and animals. The shells were probably used as raw material for making utilitarian articles. They were presumably also used to make an amulets and talismans, both categories could be associated with certain beliefs and magical treatments.

In this article have been shown that the natural aggregations of molluscs remains, not related to intentional human activity, together with the knowledge on biodiversity and the ecological requirements of individual representatives of the Mollusca type can be used in the interpretation of local environmental conditions in the past.

Translated by Mirosława Zabilska 
